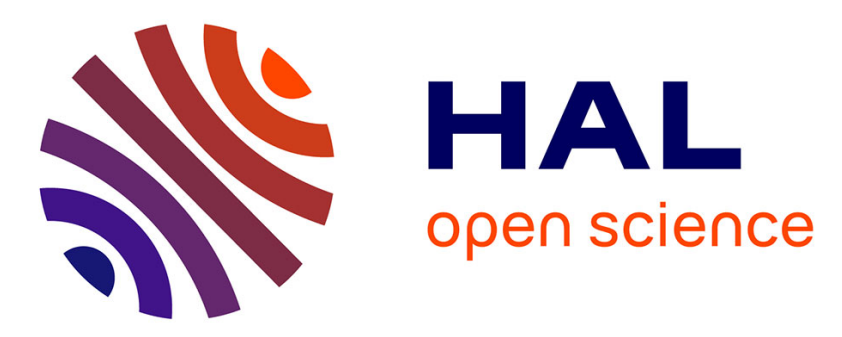

\title{
Combining Landsat observations with hydrological modelling for improved surface water monitoring of small lakes
}

A. Ogilvie, Gilles Belaud, Sylvain Massuel, M. Mulligan, P. Le Goulven, P.O. Malaterre, R. Calvez

\section{To cite this version:}

A. Ogilvie, Gilles Belaud, Sylvain Massuel, M. Mulligan, P. Le Goulven, et al.. Combining Landsat observations with hydrological modelling for improved surface water monitoring of small lakes. Journal of Hydrology, 2018, 566, pp.109-121. 10.1016/j.jhydrol.2018.08.076 . hal-02608067

\section{HAL Id: hal-02608067 https: / hal.inrae.fr/hal-02608067}

Submitted on 16 May 2020

HAL is a multi-disciplinary open access archive for the deposit and dissemination of scientific research documents, whether they are published or not. The documents may come from teaching and research institutions in France or abroad, or from public or private research centers.
L'archive ouverte pluridisciplinaire HAL, est destinée au dépôt et à la diffusion de documents scientifiques de niveau recherche, publiés ou non, émanant des établissements d'enseignement et de recherche français ou étrangers, des laboratoires publics ou privés. 


\title{
Combining Landsat observations with hydrological modelling for improved surface water monitoring of small lakes
}

\author{
Andrew Ogilvie ${ }^{\mathrm{a}, \mathrm{b}, *}$, Gilles Belaud ${ }^{\mathrm{a}}$, Sylvain Massuel $^{\mathrm{a}}$, Mark Mulligan ${ }^{\mathrm{b}}$, \\ Patrick Le Goulven ${ }^{\mathrm{a}}$, Pierre-Olivier Malaterre ${ }^{\mathrm{a}}$, Roger Calvez ${ }^{\mathrm{a}}$ \\ ${ }^{a}$ G-EAU, AgroParisTech, Cirad, IRD, IRSTEA, Montpellier SupAgro, Univ Montpellier, \\ Montpellier, France \\ ${ }^{b}$ Department of Geography, King's College London, WC2R 2LS London, UK
}

\section{Abstract}

Small reservoirs represent a critical water supply to millions of farmers 2 across semi-arid regions, but their hydrological modelling suffers from data scarcity and highly variable and localised rainfall intensities. Increased avail4 ability of satellite imagery provide substantial opportunities but the monitoring of surface water resources is constrained by the small size and rapid flood declines in small reservoirs. To overcome remote sensing and hydro7 logical modelling difficulties, the benefits of combining field data, numerical modelling and satellite observations to monitor small reservoirs were investigated. Building on substantial field data, coupled daily rainfall-runoff and water balance models were developed for 7 small reservoirs (1-10 ha) in semi arid Tunisia over 1999-2014. Surface water observations from MNDWI clas-

*Corresponding author

Email addresses: andrew.ogilvie@ird.fr (Andrew Ogilvie), gilles.belaud@supagro.fr (Gilles Belaud), sylvain.massuel@ird.fr (Sylvain Massuel), mark.mulligan@kcl.ac.uk (Mark Mulligan), patrick.legoulven@ird.fr (Patrick Le Goulven), pierre-olivier.malaterre@irstea.fr (Pierre-Olivier Malaterre), roger.calvez@ird.fr (Roger Calvez) 
sifications on 546 Landsat TM, ETM+ and OLI sensors were used to update model outputs through an Ensemble $(\mathrm{n}=100)$ Kalman Filter over the 15 year period. The Ensemble Kalman Filter, providing near-real time corrections, reduced runoff errors by modulating incorrectly modelled rainfall events, while compensating for Landsat's limited temporal resolution and correcting classification outliers. Validated against long term hydrometric field data, daily volume root mean square errors (RMSE) decreased by $54 \%$ to $31200 \mathrm{~m}^{3}$ across 7 lakes compared to the initial model forecast. The method reproduced the amplitude and timing of major floods and their decline phases, providing a valuable approach to improve hydrological monitoring (NSE increase from 0.64 up to 0.94 ) of flood dynamics in small water bodies. In the smallest and data-scarce lakes, higher temporal and spatial resolution time series are essential to improve monitoring accuracy.

Keywords: Remote sensing, Water balance, Rainfall-runoff model, Data assimilation, Ensemble Kalman Filter, Water harvesting

\section{Introduction}

\subsection{Hydrology of small water bodies}

Small reservoirs have developed across semi-arid areas to reduce transport of eroded soil and mobilise water resources for local users. Their reduced costs favoured significant bottom-up development, resulting in several million small reservoirs worldwide (Lehner et al., 2011). Due to their modest size and large numbers, field monitoring of small water bodies remains rare except for scientific purposes (Albergel and Rejeb, 1997), limiting their hydrological understanding. 
Local studies in Sub-Saharan Africa (Desconnets et al., 1997; MartinRosales and Leduc, 2003), Brazil (Molle, 1991), Mexico (Avalos, 2004), India (Massuel et al., 2014b) and Tunisia (Grunberger et al., 2004; Zammouri and Feki, 2005) performed water balance modelling to quantify available resources and hydrological processes illustrated in figure 1. These exploit field measurements of rainfall, reservoir stage and pan evaporation but difficulties occur due to the uncertainties in estimating inflow, infiltration and groundwater inflow, withdrawals and lake evaporation (Li and Gowing, 2005), which must be modelled, extrapolated and/or neglected based on reasonable assumptions. Inflow due to diffuse runoff is often assessed indirectly by closing the water balance or through rainfall-runoff modelling. The latter notably suffer from the spatial variability of semi-arid rainfall regimes, leading to model performance of NSE $=0.5$ or less, even with site specific field data (Lacombe et al., 2008; Neppel et al., 1998; Ogilvie, 2015). Difficulties increase when seeking to upscale site specific data and model water resources in ungauged small reservoirs (Cudennec et al., 2007; Hrachowitz et al., 2013).

As a result, limited information exists on their water resources, preventing the optimisation of farming practices and local stakeholder investments (Wisser et al., 2010). Capturing runoff and favouring evaporation and infiltration, these reservoirs also modify the spatio-temporal distribution of resources. Hydrological studies have shown these can reduce downstream flows by up to $80 \%$ in small catchments and highlighted their cumulative influence in larger catchments (Ma et al., 2010; Nyssen et al., 2010). Studies in China (Gao et al., 2011; He et al., 2003) and Tunisia (Kingumbi et al., 2007; Lacombe et al., 2008; Ogilvie et al., 2016b) on catchments over $1000 \mathrm{~km}^{2}$ 


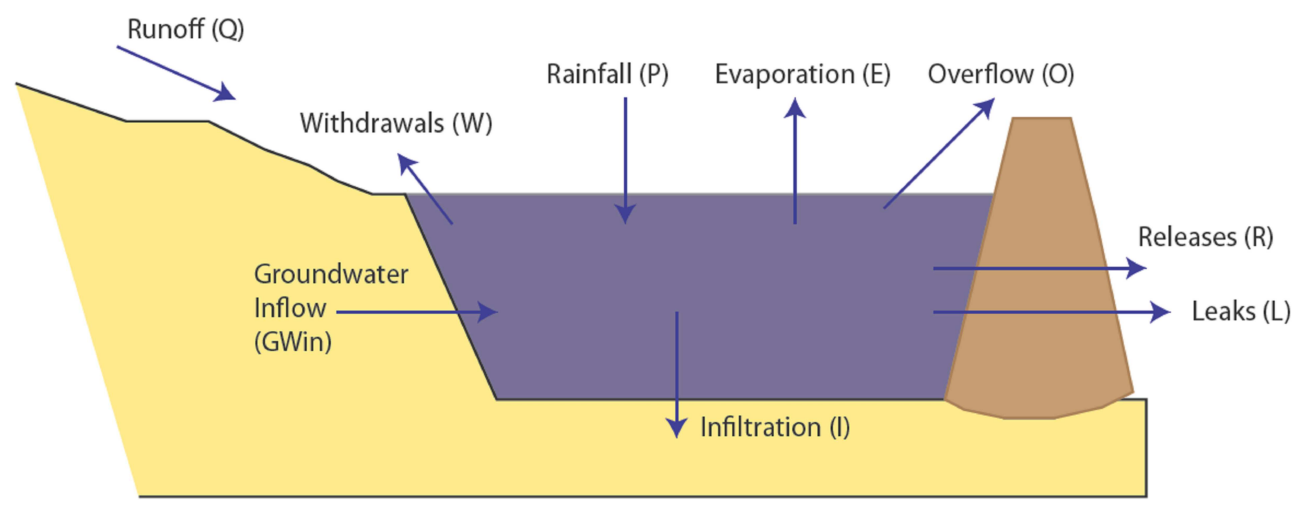

Fig. 1. Water balance fluxes in small reservoirs

ide

cat data scarcity on small reservoirs.

\subsection{Remote sensing and data assimilation of small water bodies}

Satellite imagery is increasingly exploited to provide input data or to calibrate hydrological models, with remotely sensed values of evaporation, rainfall and soil moisture (Soti et al., 2010; Zribi et al., 2011) or assessments of surface water areas (Leauthaud et al., 2013; Ogilvie et al., 2015; Swenson and Wahr, 2009), lake and river stages (da Silva et al., 2014), and lake water volumes (Baup et al., 2014; Crétaux et al., 2015; Frappart et al., 2018). Used extensively across large wetlands, lakes or rivers, and at continental or global scales, remote sensing has also been applied to provide insights across smaller water bodies.

Studies using Landsat $30 \mathrm{~m}$ or pansharpened $14.5 \mathrm{~m}$ (Feng et al., 2016) notably enabled mapping numerous water bodies and their storage capacities 
(Liebe et al., 2005; Sawunyama et al., 2006). Long term Landsat time series have also recently been used to monitor surface water variations over time. Pekel et al. (2016) developed a publicly available global data set of surface water at a monthly scale over 1984-2015. Ogilvie et al. (2018) showed the benefits of a specific approach to monitor small reservoirs $(<10$ ha) and account for the greater presence of flooded vegetation (Mueller et al., 2016; Yamazaki and Trigg, 2016) and difficulties resulting from limited spatial (30 m) and temporal resolution (up to 8 day from the combination of Landsat 8 and Landsat 7 satellites). These succeeded in reducing mean surface water RMSE to $9300 \mathrm{~m}^{2}(\mathrm{NRMSE}=24 \%)$ but the presence of clouds reduced image availability reducing the method's ability to detect rapid floods and reproduce coherent flood declines.

Data assimilation seeks to combine external sources of data or observations to beneficially correct or calibrate in real time (i.e. as observations become available) model outputs. Widely relied on in meteorology, it has become increasingly used in other scientific fields, including hydrology (Beven and Freer, 2001; Boulet et al., 2002; Clark et al., 2008; Emery et al., 2017; Moradkhani et al., 2005; Xie and Zhang, 2010) notably to combine the benefits of increasingly available and valuable (precise, accurate, higher temporal and spatial resolution) remote sensing data.

To overcome the difficulties in monitoring surface water variations in small reservoirs through hydrological modelling and satellite imagery, the benefits of combining field data, numerical modelling and remote sensing were investigated here. A daily hydrological model to simulate volumetric changes in small reservoirs combined with an Ensemble Kalman filter to reevaluate in 


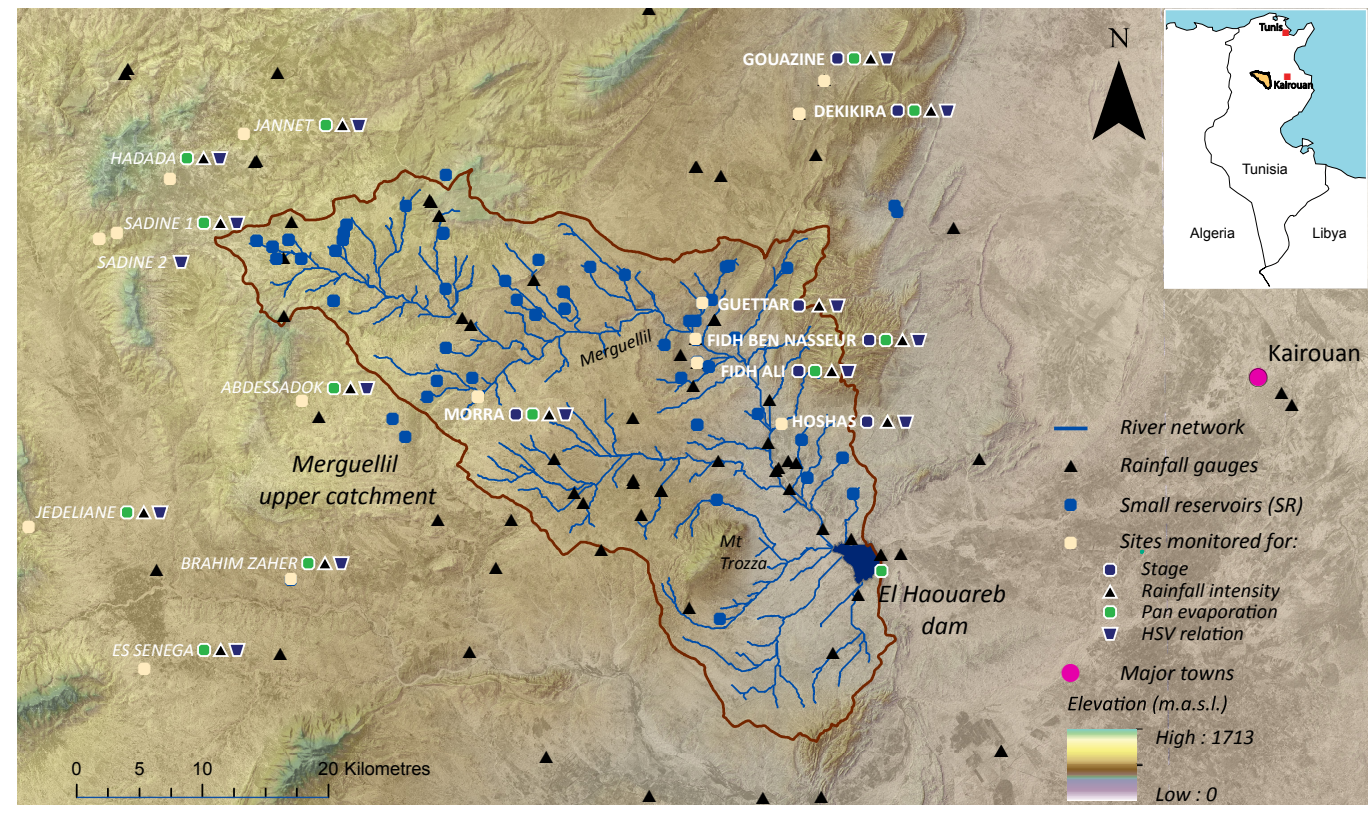

Fig. 2. Location of Merguellil upper catchment and of neighbouring hydrometeorological data used in the paper. In bold, the 7 modelled reservoirs.

real time model outputs based on Landsat observations was developed here. The benefits of this combined model on daily values and mean annual availability were assessed against field data on 7 gauged reservoirs and compared with results obtained using only hydrological modelling or Landsat observations. Finally, the sensitivity of the approach to downgrading the confidence in input values and moving towards conditions found on ungauged reservoirs was investigated.

\section{Methods}

\subsection{Study sites}

This research focussed on seven small reservoirs in semi-arid central Tunisia (figure 2) benefiting from long term hydroclimatic data acquired through re- 


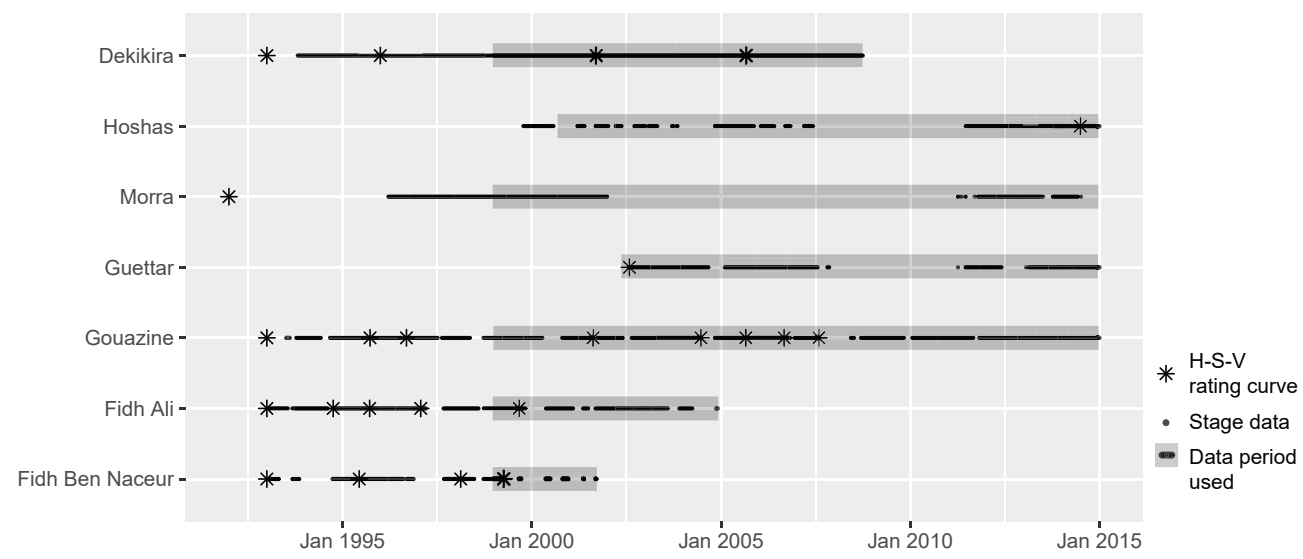

Fig. 3. Availability of stage field data and rating curves over modelling periods of the 7 lakes

search collaboration with government agencies (Albergel and Rejeb, 1997; Leduc et al., 2007; Ogilvie, 2015). Field instrumentation on each lake consisted of automatic stage pressure transducers and tipping bucket rainfall gauges, supplemented by daily limnimetric (ladder) and rainfall readings by local observers. Thirteen lakes in the vicinity had also been equipped with evaporation pans. Complementary pressure transducers and automatic rainfall gauges were installed as part of this research in 2011 on three lakes (Hoshas, Morra, Guettar) to extend time series (figure 3) and tend to the declining monitoring network exacerbated by the Tunisian revolution.

Stage and surface area were converted using site specific Height-SurfaceVolume relations (figure 3) acquired and updated since the 1990s to account for silting (Albergel and Rejeb, 1997). Complementary surveying was also carried out on Hoshas in 2014. Figure 4 illustrates the shift in the rating curves from silting, which can be used to assess the level of uncertainty associated with volumes in recent years. On Gouazine, after 6 years (2001 


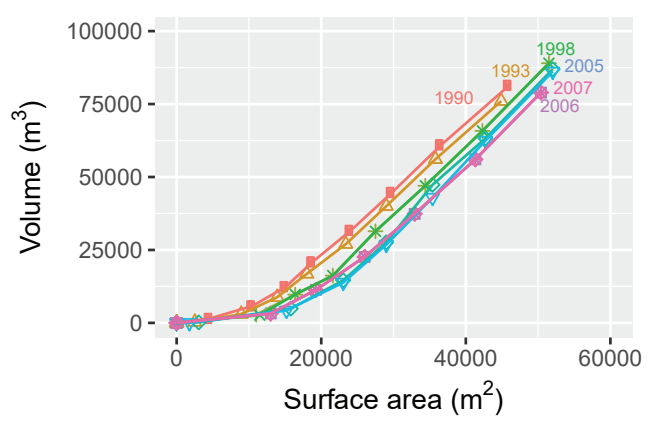

(a) Gouazine

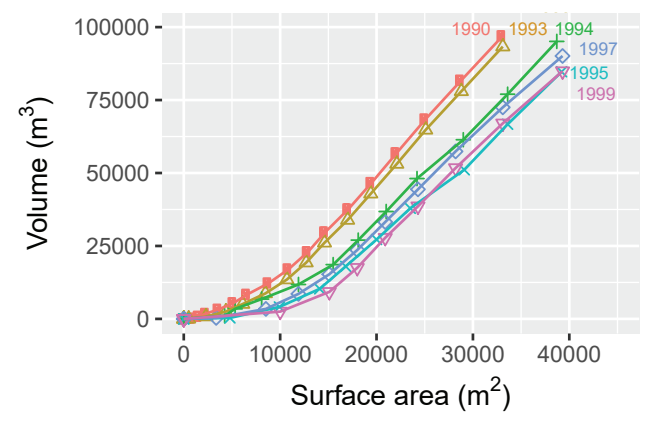

(b) Fidh Ali

Fig. 4. Change over time of surface area - volume rating curves for two small lakes

vs. 2007) the obsolescence of the rating curve results in a mean RMSE of $4900 \mathrm{~m}^{3}$, while on Fidh Ali it reaches $25000 \mathrm{~m}^{3}$ on volumes under 80 $000 \mathrm{~m}^{3}$. On lakes where rating curves could not be updated (Guettar and Morra) for logistical reasons (cost, access to lakes and presence of water and/or vegetation on lake bed), GPS contours nevertheless highlighted that errors in the H-S rating curves only reached $11-12 \%$ after 12 and 22 years respectively (Ogilvie et al., 2018).

These are inferior to errors generated from extrapolating capacity loss based on studies on 15 nearby surveyed reservoirs (figure 2), due to the strong disparities in silting rates and the difficulties in erosion modelling, especially over extended periods (Albergel and Rejeb, 1997; Baccari et al., 2008; Hentati et al., 2010; Lacombe, 2007; Ogilvie, 2015). The Gouazine reservoir benefited from the longest and most reliable time series (figure 3) due to regular maintenance, field observations and six updates to the stage-surface-volume rating curves but results on other reservoirs enabled to confront the method on lakes of different capacities ranging between $50 \mathrm{~m}^{3}$ 


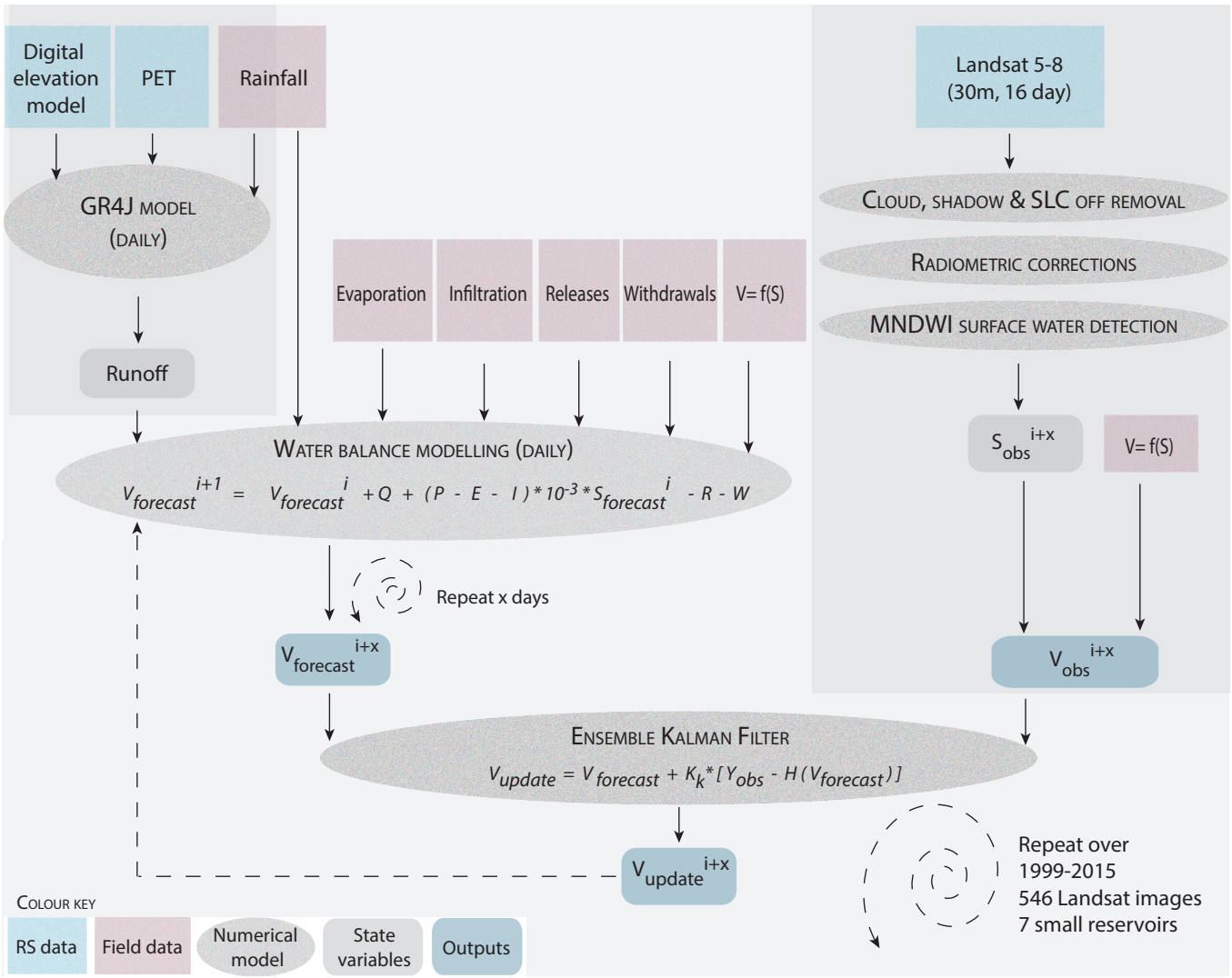

Fig. 5. Schematic representation of methodology for assimilation of Landsat observations into hydrological model with the Ensemble Kalman Filter

and $700000 \mathrm{~m}^{3}$ (table 1).

The field data collected were used to estimate the multiple fluxes in the water balance (WB) of small lakes and develop rainfall-runoff models for their catchments. Site specific hydrological models were developed over 1999-2014 for seven lakes, before evaluating the benefits of integrating earth observation data, as illustrated in figure 5 . 


\subsection{Water balance modelling of 77 small water bodies}

\subsubsection{Rainfall inputs}

Daily rainfall $(P, \mathrm{~mm} /$ day) over the 7 lakes was interpolated over 19992014 from the 50 manual and automatic rainfall gauges situated at the lakes and within and around their catchments (figure 2). Inverse Distance Weighting (IDW) interpolation was used after tests showed the marginal benefit (error reduction by $1 \mathrm{~mm}$ ) (Ogilvie, 2015) of geostatistical methods such as Kriging with external drift (Hengl et al., 2007) compared to the lengthy treatment times. Mean rainfall varied between $299 \mathrm{~mm} /$ year $\pm 108 \mathrm{~mm} /$ year to $396 \mathrm{~mm} /$ year $\pm 124 \mathrm{~mm} /$ year (table 1 ). The homogeneous distribution of the rainfall gauges in this catchment inherently accounts for the altitudinal gradient within subcatchments (Feki et al., 2012; Ogilvie et al., 2016b; Van Der Heijden and Haberlandt, 2010; Wackernagel, 2004).

\subsubsection{Lake evaporation}

Lake evaporation rates $(E, \mathrm{~mm} /$ day $)$ were IDW interpolated based on field observations from Colorado type sunken pans on 13 lake shores over 1999-2008 (figure 2). Evaporation time series were completed to 2015 based on linear regressions between each lake and a reference station with continuous observations (El Haouareb), assuming homogeneous evaporation variations across the basin $\left(R^{2}=0.92\right)$. Potential lake evaporation varied across lakes between $1776 \mathrm{~mm} /$ year $\pm 143 \mathrm{~mm} /$ year to $2019 \mathrm{~mm} /$ year $\pm 198 \mathrm{~mm} /$ year (table 1). A pan coefficient $\left(C_{t}\right)$ of 0.8 based on water bodies of similar sizes in semi-arid areas was used (Alazard et al., 2015; Cadier, 1996; Linacre, 1994; McMahon et al., 2013; Molle, 1991; Riou, 1972). 


\subsubsection{Infiltration rules}

Infiltration $(I, \mathrm{~mm} /$ day $)$ was modelled based on equation 1 where $Z_{\text {water }}$ is the absolute head of water $(\mathrm{mm}), a$ the slope, and $i_{0}(\mathrm{~mm} /$ day $)$ the intercept values provided in table A.1. These were extracted from Lacombe (2007) and estimated for Guettar, Dekikira and Hoshas (figure 6) during depletion phases (respectively 1262, 651 and 1546 days) when other fluxes are absent (rainfall, runoff, withdrawals, releases) based on stage monitoring and estimated evaporation (Lacombe, 2007; Ogilvie, 2015). Mean daily infiltration varied between $2 \mathrm{~mm}$ and $28 \mathrm{~mm}$ for a lake on gravely soil (table 1). Recent data do not indicate a noticeable change in infiltration properties from silting over time, confirming past observations (Lacombe, 2007). Similarly, uncertainties from silting on the absolute head of water used in infiltration rules are estimated on average at $12.5 \%$ per metre, and may be lower due to partial silting of the lake floor and constant infiltration rates observed on four of these lakes (Ogilvie, 2015). Groundwater and subsurface inflow are often neglected in water budgets (Lacombe, 2007; Li and Gowing, 2005) as these are minor fluxes and their quantification requires intense monitoring and geochemical methods (Massuel et al., 2014b; Montoroi et al., 2002). Accordingly, infiltration estimates provided here may in some cases correspond to the combination of infiltration, leaks and groundwater inflow. On Gouazine, groundwater inflow was shown to reach $50 \mathrm{~m}^{3}$ /day (Grunberger et al., 2004), meaning absolute infiltration may be up to $2.5 \mathrm{~mm} /$ day greater when the lake is 2 ha and less when surface area rises (Ogilvie, 2015).

$$
I=i_{0}+a * Z_{\text {water }}
$$




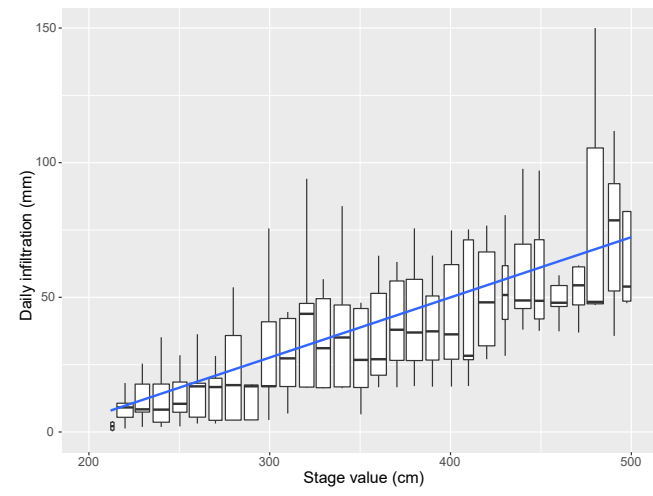

(a) Hoshas

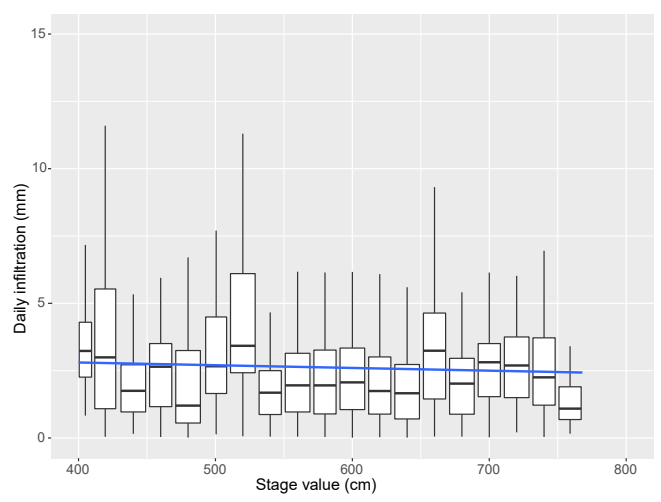

(b) Dekikira

Fig. 6. Infiltration values as a function of stage in the lake estimated during depletion periods

\subsubsection{Modelling releases and overflows}

Semi-structured interviews with the dam operators revealed the absence of strict rules to protect the infrastructure as releases depended on further storm forecasts, government advice, presence of lakes downstream, technical problems with the valve and pressure from users to maintain maximal resources for the dry season (Ogilvie, 2015). Releases ( $R, \mathrm{~m}^{3} /$ day) were detected on two lakes after only the most significant events (1\% of all events). Based on the extraordinary decline rates witnessed in instantaneous (15 min) hydrometric data, releases were modelled on the basis of a $10000 \mathrm{~m}^{3}$ /day release to reach $80 \%$ of $V_{\max }$ if and when the latter is exceeded (Lacombe, 2007; Ogilvie, 2015). This also accounts for overflows through the spillway. Minor releases to flush out sediments and vegetation from the conduit were increasingly rare and remain of the order of 1000-5000 $\mathrm{m}^{3} /$ year. 
Table 1: Characteristics of the 7 small reservoirs modelled and their catchments

\begin{tabular}{lllllll}
\hline Lake & $\begin{array}{l}\text { Catchment } \\
\text { size }\left(\mathrm{km}^{2}\right)\end{array}$ & $\begin{array}{l}\text { Altitude } \\
(\mathrm{m})\end{array}$ & $\begin{array}{l}\text { Initial capacity } \\
\left(10^{3} \mathrm{~m}^{3}\right)\end{array}$ & $\begin{array}{l}\text { Rainfall } \\
(\mathrm{mm} / \text { year, } \\
1999-2014)\end{array}$ & $\begin{array}{l}\text { Evaporation } \\
(\mathrm{mm} / \text { year, } \\
1999-2014)\end{array}$ & $\begin{array}{l}\text { Infiltration } \\
(\mathrm{mm} / \text { day, } \\
1999-2014)\end{array}$ \\
\hline Dekikira & 3.31 & 406 & 219 & 396 & 1842 & 2.7 \\
\hline Hoshas & 7.90 & 306 & 130 & 302 & 2003 & 28 \\
\hline Guettar & 4.98 & 393 & 150 & 339 & 1994 & 10 \\
\hline Gouazine & 16.64 & 397 & 237 & 387 & 1776 & 9 \\
\hline Fidh Ali & 2.74 & 350 & 134 & 324 & 2019 & 3.6 \\
\hline Fidh Ben Nasseur & 1.82 & 368 & 47 & 327 & 2016 & 7.8 \\
\hline Morra & 11.69 & 588 & 705 & 299 & 1917 & 2 \\
\hline
\end{tabular}

\subsubsection{Modelling withdrawals}

Regular field visits and quantitative questionnaires with 48 farmers on 22 lakes (Ogilvie, 2015) revealed the extreme heterogeneity of pumping practices across lakes and years but highlighted the absence, or reduced importance of withdrawals $\left(W, \mathrm{~m}^{3} /\right.$ day) on most lakes. These represented less than 40 $\mathrm{m}^{3} /$ day in the summer months, compared to the $340 \mathrm{~m}^{3}$ /day from infiltration (of $7 \mathrm{~mm}$ ) and evaporation (10 mm) on a small (2 ha) surface area (Lacombe, 2007; Ogilvie, 2015). On Guettar and Morra lakes however, withdrawals to water fruit trees were estimated to reach over $130 \mathrm{~m}^{3} /$ day over April to October. No withdrawal restrictions to preserve the resource as it wanes were observed and thus modelled (Ogilvie, 2015).

\subsection{Runoff estimation through GR4J catchment modelling}

Runoff $\left(Q, \mathrm{~m}^{3} /\right.$ day) into small reservoirs was assessed using a daily GR4J rainfall-runoff model developed for each reservoir's catchment. This lumped conceptual model is well suited to the relative scarcity of data and used 
across semi-arid catchments of comparable size (Perrin et al., 2003). A daily time step was used to capture the intense rainfall events and corresponds to the available rainfall and runoff data, as availability of sub-daily data is extremely limited. It relies on a simple two reservoir structure and four parameters:

- $X 1$ production store capacity $(\mathrm{mm})$

- $X 2$ groundwater exchange coefficient (mm/day)

- $X 3$ routing store capacity $(\mathrm{mm})$

- X4 unit hydrograph time constant (day)

Input variables consist of catchment size delineated using 1 arc second SRTM digital elevation model, rainfall $(P, \mathrm{~mm} /$ day $)$ IDW interpolated from available observations across over 50 gauges (figure 2) and potential evapotranspiration (PET, mm/day) interpolated from 180 MODIS-derived $1 \mathrm{~km}^{2}$ monthly tiles. These MOD16 datasets exploit global weather data sets combined with MODIS derived land cover types, leaf area index and albedo $(\mathrm{Mu}$ et al., 2011) to provide monthly PET estimates, at a higher resolution than the $0.5^{\circ}$ Climate Research Unit products.

Models were calibrated using an objective function of maximal Nash Sutcliffe Efficiency (NSE) on runoff. $Q_{o b s}$ was estimated based on stage monitoring (figure 3) and a simplified water balance equation, as diffuse sheet runoff and subsurface runoff prevent direct observations (Albergel et al., 2003; Lacombe et al., 2008). Several fluxes can be neglected (groundwater 
inflow, leaks) or assumed null (e.g. withdrawals) during the violent Hortonian runoff events resulting from limited vegetation, low soil water holding capacities, prominent topography and high rainfall intensity characteristic of Mediterranean climates (Lacombe et al., 2008). The other water balance fluxes ( $P, E, I$, releases, overflows) were assessed based on local monitoring and observations as described previously. The airGR code (Coron et al., 2017) which allowed for integrated numerical modelling and remote sensing processing in $\mathrm{R}$, as well as superior results thanks to the HBAN optimisation function, was used.

\subsection{Combining remote sensing observations and hydrological modelling}

\subsubsection{Landsat surface water observations}

The remote sensing observations employed in the Ensemble Kalman Filter were Landsat-derived surface water areas for each lake over 1999-2014. 526 Landsat 5-8 images available freely from USGS were corrected to surface reflectance and filtered to remove acquisitions with excessive clouds, shadows and inactive Scan Line Corrector (SLC-off) pixels over each lake. Flooded areas were extracted using the Modified Normalised Difference Water Index $(\mathrm{Xu}, 2006)$ calibrated against extensive field data. Full details of the approach are available in Ogilvie et al. (2018) and led to a mean surface area RMSE of $9300 \mathrm{~m}^{2}$. Surface areas were converted to volumes using the available rating curves and values were linearly interpolated to provide a continuous time series and allow comparisons with field data $\left(V_{\text {field }}\right)$ and the Ensemble Kalman Filter $\left(V_{E N K F}\right)$ outputs. Alternate interpolation approaches (Forkel et al., 2013) to gap fill and smooth daily time series failed here to provide significant benefit, partly due to the abrupt fluctuations observed contrasting 
with gradual seasonal flood pulses in larger water bodies (Leauthaud et al., 2013; Ogilvie et al., 2015).

\subsubsection{Ensemble Kalman Filter}

Ensemble Kalman Filtering (ENKF, Evensen (2003)) is a stochastic data assimilation method suited to smaller scale non-linear systems, including where initial states are highly uncertain (Gillijns et al., 2006) as may be the case due to poor rainfall-runoff modelling of intense rainfall events. It also reduces the difficulties associated with developing a tangent linear model and deriving its adjoint counterpart (Vermeulen and Heemink, 2006), required in variational data assimilation (e.g. 3D-Var, 4D-Var), widely used in the modelling of large systems such as atmospheric circulation models, oceanography, and more recently in hydrology and hydraulics applications (Oubanas et al., 2018).

With the Kalman filter, an initial forecast is updated using the Kalman gain when an external observation is available, based on the following equations:

$$
\begin{gathered}
V_{\text {update }}=V_{\text {forecast }}+K_{k} *\left[Y_{\text {obs }}-H\left(V_{\text {forecast }}\right)\right] \\
Y_{\text {obs }}=H\left(V_{\text {obs }}\right)+v_{k}
\end{gathered}
$$

where $K_{k}$ is the Kalman gain defined as:

$$
K_{k}=C y * H^{T} *\left(H * C w * H^{T}+C v\right)^{-1}
$$


$V_{\text {forecast }}$ is here the lake volume outputted by our daily hydrological model $f(V)$ with a random error $w_{k}$.

$$
V_{\text {forecast }}=f(V)+w_{k}
$$

$H$, called the observation operator, is the model to convert observed state variables to observations. Where observations are directly inputted, as in this case, $H=$ Id (identity) and equations simplify as below (equations 6 and 7). The external observation is the remotely sensed lake volume based on Landsat imagery $\left(V_{R S}\right)$ which have an associated random error $v_{k}$.

$$
\begin{gathered}
K_{k}=C y *(C w+C v)^{-1} \\
V_{\text {update }}=V_{\text {forecast }}+K_{k} *\left[V_{o b s}+v_{k}-V_{\text {forecast }}\right]
\end{gathered}
$$

which can here be rewritten as:

$$
V_{E N K F}=K_{k} *\left(V_{R S}+v_{k}\right)+\left(1-K_{k}\right) * V_{W B+G R 4 J}
$$

The forecast step is repeated on a daily basis and $V_{\text {forecast }}$ is updated when acceptable Landsat observations are available (equation 8). The updated volume $\left(V_{E N K F}\right)$ is then fed back into the daily hydrological model and sequentially updated over 1999-2014 with the valid remote sensing (RS) observations (figure 5).

$C v$ is the observation error covariance matrix, $C w$ is the forecast error covariance matrix and $C y$ is the cross covariance matrix between the state variable and the forecast. As the state variable used is the volume and not 
an intermediary state variable, $C y$ is equivalent to $C w$. $C v$ and $C w$ values were estimated using the covariances of errors between stage observations and remote sensing observations and between stage and model outputs respectively. Stage related volumes include their own element of error (ladder readings, rating curve imprecisions and evolving flood bed topography) but here these are neglected compared to the errors from remote sensing (incl. radiometric corrections, detection errors) and hydrological modelling. $C w$ variance was 20 times greater than $C v$ variance and contributed to attributing greater confidence to the Landsat values over the model outputs in the Kalman filtering. Alternate combinations were tested but these did not lead to performance improvements. $C w$ remained constant as recommended by Clark et al. (2008), allowing the method to be used on periods and lakes with non-continuous ground truth data.

In the Ensemble version of the Kalman filter, $n$ values of the initial state are generated and each ensemble member is run through the forecast and update step. The $n$ values of the initial state are generated based upon a random synthetic error $y$ so that values have mean value initial state and predefined covariance $C y$. Initial states are the same as $V$ (equation 5) and not an intermediary variable, so $y$ was taken to be $w_{k}$, the forecast error (Moradkhani et al., 2005). The $n$ ensemble of external observations are generated randomly to obtain a normal (Gaussian) distribution with error $v_{k}$, i.e. centred on the observation value and with predefined covariance $C v$ (Reichle et al., 2002). Here $n=100$, as Gillijns et al. (2006) reveal marginal benefits above 100 and greater errors for $n$ values below 40 . 


\subsection{Performance and sensitivity of the ENKF approach}

The performance of the Ensemble Kalman Filter $\left(V_{E N K F}\right)$ was assessed against available field data $\left(V_{\text {field }}\right)$ and compared with the performance of using only hydrological model $\left(V_{W B+G R 4 J}\right)$ and only remote sensing $\left(V_{R S}\right)$ data. NSE values were calculated but considering their sensitivity to timing of outputs and ability to disguise certain errors (Moussa, 2010), RMSE values were provided. The performance in terms of individual daily volumes was investigated as well as on annual water availability, considering their importance to local users.

The method's performance, as inputs and parameters were degraded, was then tested on four lakes to study its sensitivity and identify the ability of RS observations to correct for greater uncertainties. The influence of reduced rainfall observation networks was considered, based on rainfall time series interpolated after artificially removing gauges in the catchment. Information gathered across 15 gauged reservoirs was also used to consider the applicability of the approach to nearby ungauged catchments based on average infiltration rules, transposing GR4J parameters and modeling an average surface volume power relation adapted for silting over time detailed in Ogilvie et al. (2016a).

\section{Results and discussion}

\subsection{Hydrological modelling of small water bodies}

Figure 7 illustrates the daily volume dynamics on lake Gouazine simulated by the hydrological model. Compared to the long term field observations, 
results highlight the ability of the model to reproduce coherent flood dynamics and declines rates, for floods of varying amplitudes. Flood peaks were however, in some cases, under and over estimated as in 2003 (-54\%) or $2007(+198 \%)$ according to field data on lake Gouazine. Difficulties occurred due to the low performance of the GR4J rainfall-runoff model, where NSE reached values around $0.5-0.6$ on Gouazine and Dekikira, but nearer $0.2-0.3$ on other lakes (table 2), notably on lakes with less extensive and reliable field data (rainfall, stage and rating curves). Though low, these are comparable to previous GR4J results in the basin (Lacombe, 2007) and due largely to insufficient rainfall gauge densities which fail to capture the high intensities of very localised rainfall events (Neppel et al., 1998).

\subsubsection{Rainfall-runoff modelling limitations}

To simulate the uncertainties from the absence of upstream rainfall gauges in the catchments of small reservoirs, rainfall was interpolated for the Gouazine catchment after artifically excluding its upstream gauge data. IDW interpolated rainfall was then underestimated by $20.3 \%$ on 44 out of 53 events over 20 mm. The performance of the GR4J model decreased marginally (NSE $=0.55)$, however for the combined WB+GR4J model NSE declined from 0.57 to 0.24, due to the knock on effect of errors during the flood decline (e.g. floods missed in 2012 and 2014 in figure 12). Conversely, rainfall underestimation forced the model during calibration to increase runoff coefficients, leading to overestimation on other events which had been accurately detected due to their larger spatial extent. These results highlight the importance of reliable upstream gauges to detect orographic rainfall intensities and the order of magnitude of uncertainties in catchments where upstream stations are 
Author-produced version of the article published in Journal of Hydrology, 2018, N566, p. 109-121.

The original publication is available at https://www.sciencedirect.com

Doi: 10.1016/j.jhydrol.2018.08.076

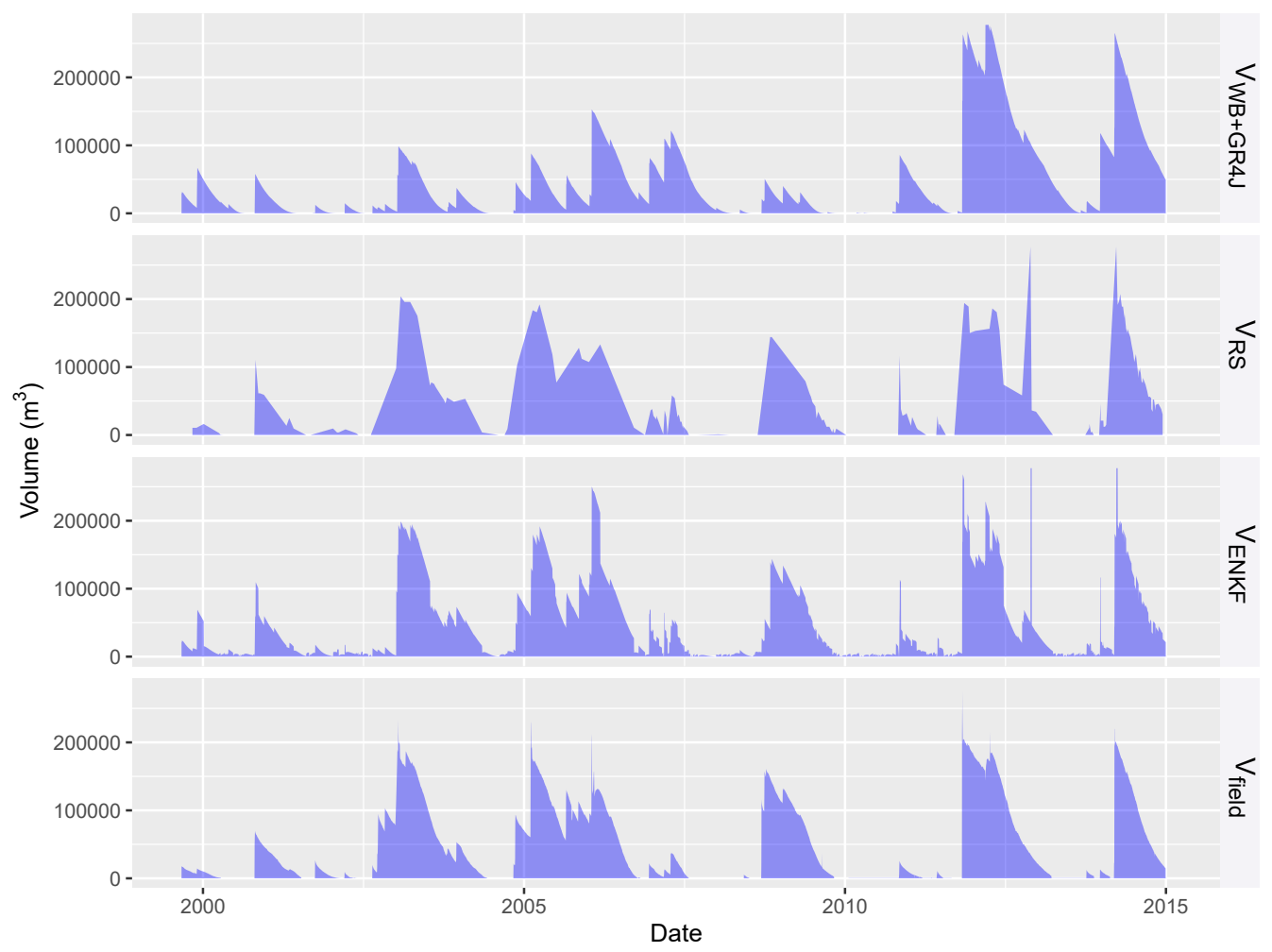

Fig. 7. Comparing observed daily volumes $\left(V_{\text {field }}\right)$ for Gouazine lake, 1999-2014 with values obtained by the hydrological model $\left(V_{W B+G R 4 J}\right)$, the remote sensing observations $\left(V_{R S}\right)$ and their combination through Ensemble Kalman Filtering $\left(V_{E N K F}\right)$ 
unavailable (i.e. all here, except Gouazine).

Even with an upstream station, certain events were underestimated on Gouazine (in 2003, 2005, and 2009 on figure 7) due to undetected localised storm cells. At the event scale, altitude variograms (e.g. KED) were not sufficient either to correctly modulate over space the amplitude of events. Though meteorological satellite observations (e.g. TRMM) do not provide reliable estimates at the event scale on such small catchments $\left(<20 \mathrm{~km}^{2}\right)$, these or even phone signal networks (Doumounia et al., 2014; Overeem et al., 2013) may help define variograms and improve geostatistical interpolation. In larger catchments or where the density of observations is greater, distributed models may also help account for space-time rainfall variability (Aouissi et al., 2018).

Errors from the limited rainfall gauge density were further exacerbated by inherent measurement gaps and errors due to equipment malfunctions (obstructions, low maintenance) and the absence of sub-daily time series to capture the flood peak accurately. Though $93 \%$ of storms over $10 \mathrm{~mm}$ were separated by 24 hours (Lacombe, 2007), certain large events were poorly modelled as substantial rains scattered over successive days, led to very high runoff on the third day only, due to saturated soils and delayed subsurface flows, causing calibration difficulties. Furthermore, the volume of the first storms can be overestimated due to silting, and because ladders rarely monitor the lowest stage levels, due to logistical reasons of installation and regular access. 


\subsubsection{Heterogeneous catchment responses}

The low GR4J performance partly translated difficulties to model the catchment's response. The intensity but also land cover, antecedent soil humidity or conservation works such as contour benches can significantly influence runoff coefficients in these catchments as discussed in (Ogilvie et al., 2016b). Model parameter $X 1$ notably seeks to account for the soil humidity and the threshold effect, leading to greater runoff once $X 1$ is saturated. The lumped (i.e. not spatialised) nature of the GR4J model makes accounting for localised changes in catchment behaviour (water conservation works, land cover and cropping) difficult however. Model choice guided by limited data availability precluded the selection of a more data intensive semi-distributed and/or physical model capable of accounting for discrete changes over time in land cover and land use. Changing model parameters over time can alternatively indirectly account for this but only at the catchment scale. On Gouazine, where numerous studies discuss the possible reduction in runoff from the development of contour benches on $43 \%$ of its catchment area (Nasri, 2007), calibrating over 1997-2003 led to a routing store capacity (X3 parameter) 5 times greater than over the whole period, possibly pointing to the greater retention capacity from water soil and conservation works. Model performance improved (NSE rose to 0.67 ) but only marginally as it remained affected by the other difficulties discussed above.

\subsection{Combining remote sensing and hydrological modelling}

\subsubsection{Ensemble Kalman filter performance on daily volumes}

Figure 7 compares the daily volume dynamics on lake Gouazine based on outputs from the hydrological model, the remote sensing observations, and 
their combination through the Ensemble Kalman filter. Remotely sensed volumes provided greater accuracy in the estimations of flood peaks than the hydrological model however outliers remained present (e.g. 2006 and 2013). Furthermore, the low frequency of acceptable observations (on average $1.5 /$ month) led to poor representation of the rapid flood rises as in 2003 (Ogilvie et al., 2018).

The Ensemble Kalman filter improved the performance of the site-specific hydrological models, with Landsat observations notably modulating the initial $V_{W B+G R 4 J}$ forecast and usefully correcting the flood peaks under and overestimated by the model (figure 7). These errors were carried through the decline phase of the hydrological models and figure 8 clearly illustrates the correction from the satellite observation which draws volumes closer to the 1:1 line, raising the NSE value, for instance from 0.57 to 0.81 on Gouazine. This effect was pronounced on larger lakes that do not dry out, as overestimations in the model outputs led to a progressive drift, which the ENKF usefully corrected (figure 9).

Accordingly, RMSE (table 2) reduced thanks to the Landsat corrections on 5 of the lakes (Dekikira, Gouazine, Fidh Ali, Morra and Guettar). Mean RSME reduced by $54 \%$ to $31200 \mathrm{~m}^{3}$ across all lakes and $21400 \mathrm{~m}^{3}$ when excluding the much larger dam (Morra). Compared to the range of flood values experienced by these lakes, NRMSE reached an acceptable 0.26. Greater errors were observed due in part to reduced model performance, preponderant remote sensing uncertainties (e.g. Hoshas) and less reliable hydrometric field data (HSV on Morra and Guettar). The lower NSE on the smallest reservoirs (Hoshas, Fidh Ben Nasseur) were to be expected here considering 


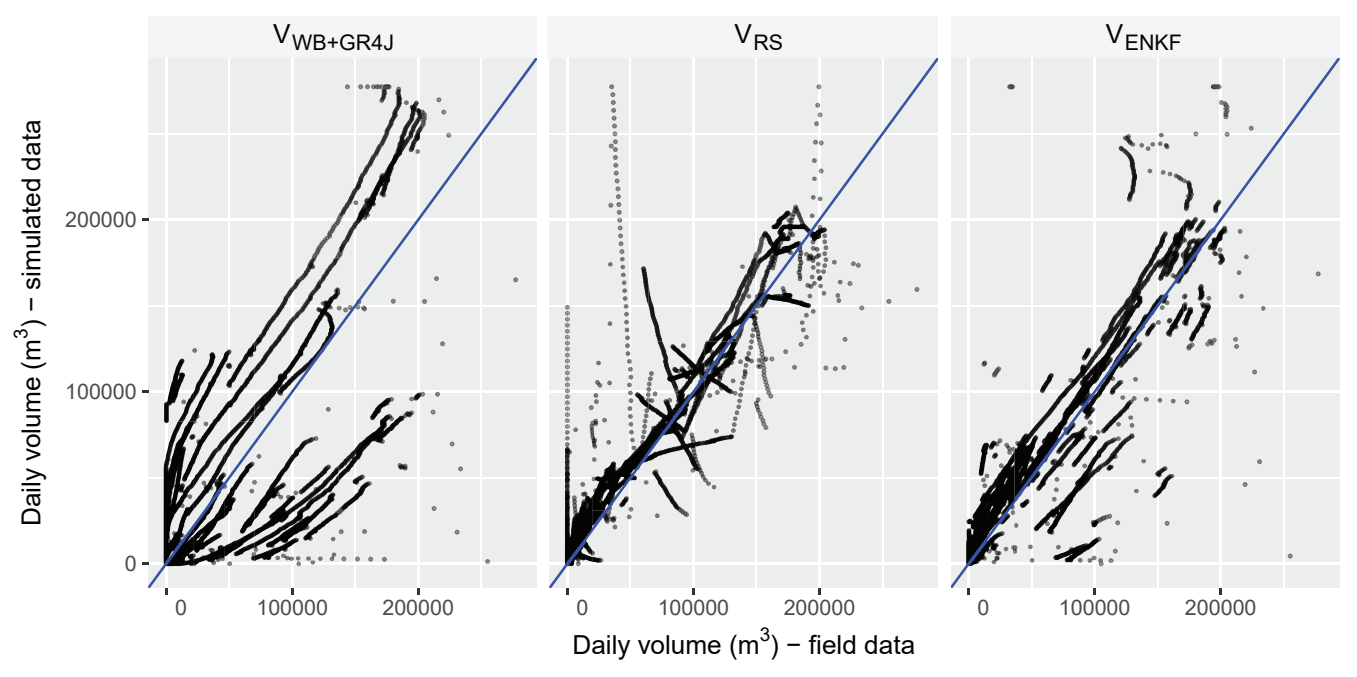

Fig. 8. Scatterplot between modelled and observed daily volumes on lake Gouazine, 1999-2014

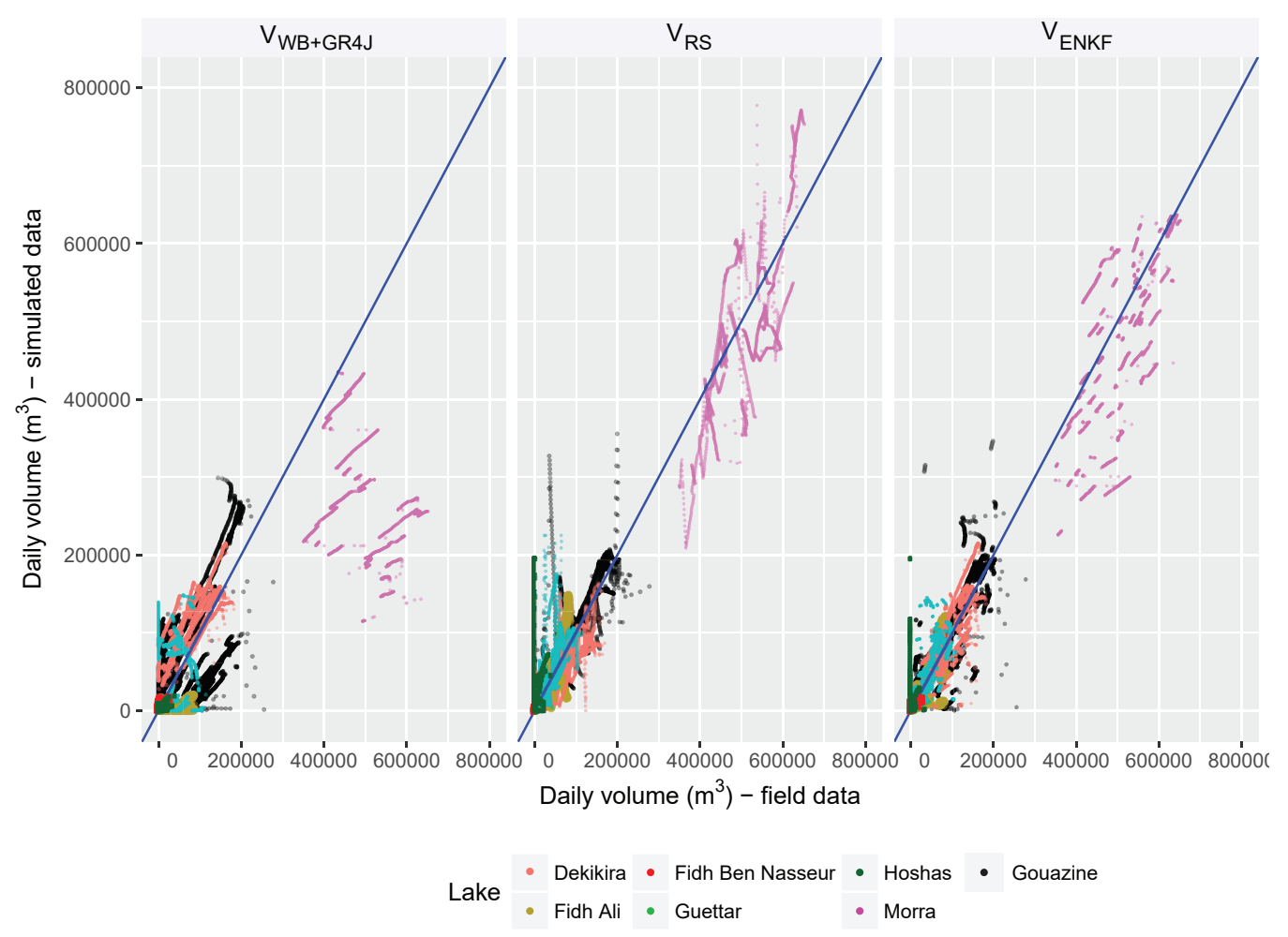

Fig. 9. Scatterplot between modelled and observed daily volumes for all 7 lakes, 1999-2014 
the spatial resolution $(30 \mathrm{~m})$ of satellite imagery used here and the mean flooded surface area around $1000 \mathrm{~m}^{2}$ (Ogilvie et al., 2018).

Remote sensing observations are capable of representing flood dynamics with low RMSE but suffer from overclassifications due to undetected clouds and from the reduced temporal resolution of Landsat imagery (on average 1.5 image/month due to clouds) (Ogilvie et al., 2018). The ENKF approach developed here enabled remote sensing outliers to be rapidly corrected here, as seen on Gouazine in 2012 (figures 7 and 8) and Morra (figure 9) for instance. The combination with rainfall-runoff modelling also reduced interpolation errors resulting from insufficient observations close to the flood peak as seen on figure 7. Similarly, the ENKF also helped identify additional flood peaks as in 2006. Over long periods, ENKF led to a reduction of RMSE near $10 \%$ on Dekikira and Guettar. Large errors in the initial forecast led to marginally higher RMSE with ENKF than $V_{R S}$ on some lakes. However, as seen in figure 7, the ENKF approach enabled a more coherent and accurate reproduction of daily flood dynamics even on these lakes. Over a single hydrological year, the reduction in RMSE from ENKF over interpolated remote sensing observations also reached up to $46 \%$ on Gouazine.

\subsubsection{Ensemble Kalman Filter performance on annual water availability}

The method's performance in assessing annual water availability rather than fine flood dynamics (i.e. individual observations) is shown in figures 10 and 11, and summarised in table 3. The ENKF method improved on the initial $V_{W B+G R 4 J}$ results $(\mathrm{NSE}=0.62)$, except on the smallest lakes (Hoshas and Fidh Ben Nasseur). Nevertheless, the orders of magnitude of the ENKF estimated volumes on Hoshas (figure 10) remain correct in comparison to 
Author-produced version of the article published in Journal of Hydrology, 2018, №566, p. 109-121.

The original publication is available at https://www.sciencedirect.com

Doi: 10.1016/j.jhydrol.2018.08.076

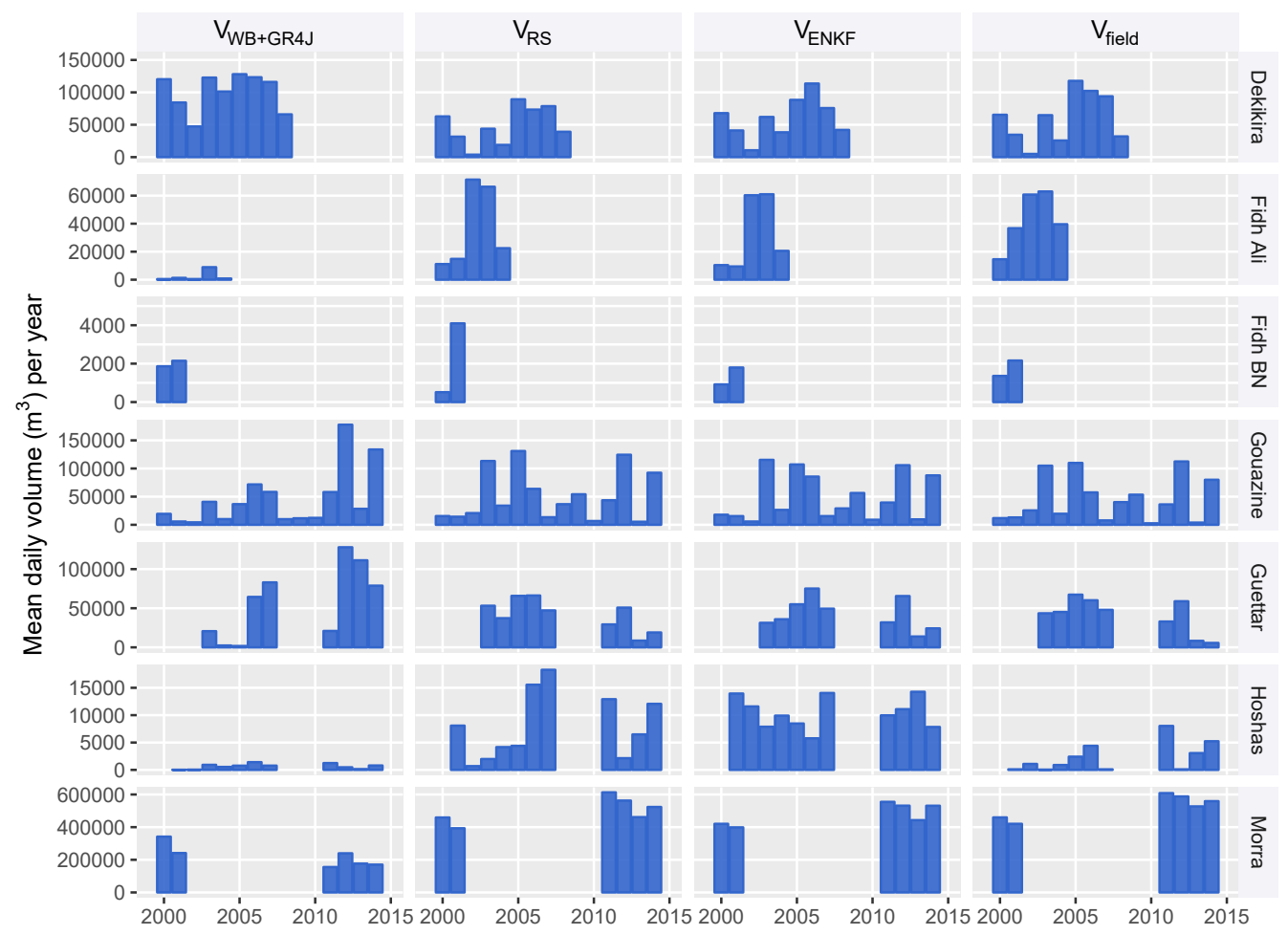

Fig. 10. Modelled and observed mean daily water volumes per year for all 7 lakes. Years with no field observations between 1999-2014 were excluded here. 
Table 2: Ensemble Kalman Filter performance on daily volumes

\begin{tabular}{|c|c|c|c|c|c|c|c|c|}
\hline \multirow{2}{*}{$\begin{array}{l}\text { Lakes (modelled } \\
\text { period) }\end{array}$} & \multirow{2}{*}{$\begin{array}{l}\text { Initial } \\
\text { capacity } \\
\left(10^{3} \mathrm{~m}^{3}\right)\end{array}$} & \multicolumn{3}{|c|}{ NSE } & \multicolumn{3}{|c|}{$\operatorname{RMSE}\left(\mathrm{m}^{3}\right)$} & \multirow{2}{*}{$\begin{array}{l}\text { NRMSE } \\
V_{E N K F}\end{array}$} \\
\hline & & $V_{W B+G R 4 J}$ & $V_{R S}$ & $V_{E N K F}$ & $V_{W B+G R 4 J}$ & $V_{R S}$ & $V_{E N K F}$ & \\
\hline Gouazine (1999-2014) & 237 & 0.57 & 0.84 & 0.81 & 45200 & 25300 & 25900 & 0.09 \\
\hline Dekikira (1999-2008) & 219 & 0.69 & 0.73 & 0.78 & 44000 & 25800 & 23700 & 0.13 \\
\hline Fidh Ali (1999-2005) & 134 & 0.17 & 0.70 & 0.55 & 39200 & 20900 & 20900 & 0.24 \\
\hline Fidh Ben Nasseur (1999-2001) & 47 & 0.45 & 0.11 & 0.44 & 6500 & 1500 & 6600 & 0.21 \\
\hline Morra (1999-2014) & 705 & 0.12 & 0.62 & 0.46 & 274300 & 76400 & 90000 & 0.30 \\
\hline Hoshas (2001-2014) & 130 & 0.48 & 0.02 & 0.02 & 3000 & 23400 & 23100 & 0.56 \\
\hline Guettar (2003-2014) & 150 & 0.18 & 0.50 & 0.49 & 62500 & 31800 & 28300 & 0.25 \\
\hline
\end{tabular}

much larger volumes on nearby lakes. Again, by modelling the decline between two Landsat observation and reducing certain outliers, the ENKF also improved upon $V_{R S}$ on certain lakes (e.g. Gouazine, Dekikira) but on others, the poor initial forecast degraded the ENKF performance (e.g. Guettar and Morra). Overall, ENKF displayed superior results than on individual values due to the annual smoothing of observations, leading to very high levels of NSE (0.99 across all lakes) and a mean RMSE (excluding the larger Morra dam) reduced here to $10500 \mathrm{~m}^{3}$.

On Hoshas, $V_{W B+G R 4 J}$ continued to perform better than $V_{E N K F}$ despite underestimating all events, due to the small and short floods experienced which lead to a drastic, incorrect increase in water availability from single remote sensing outliers. These were removed here through cloud and shadow filtering and capping volume outputs to the known maximum capacities, however residual outliers due to undetected cirrus clouds or shadows remain. 


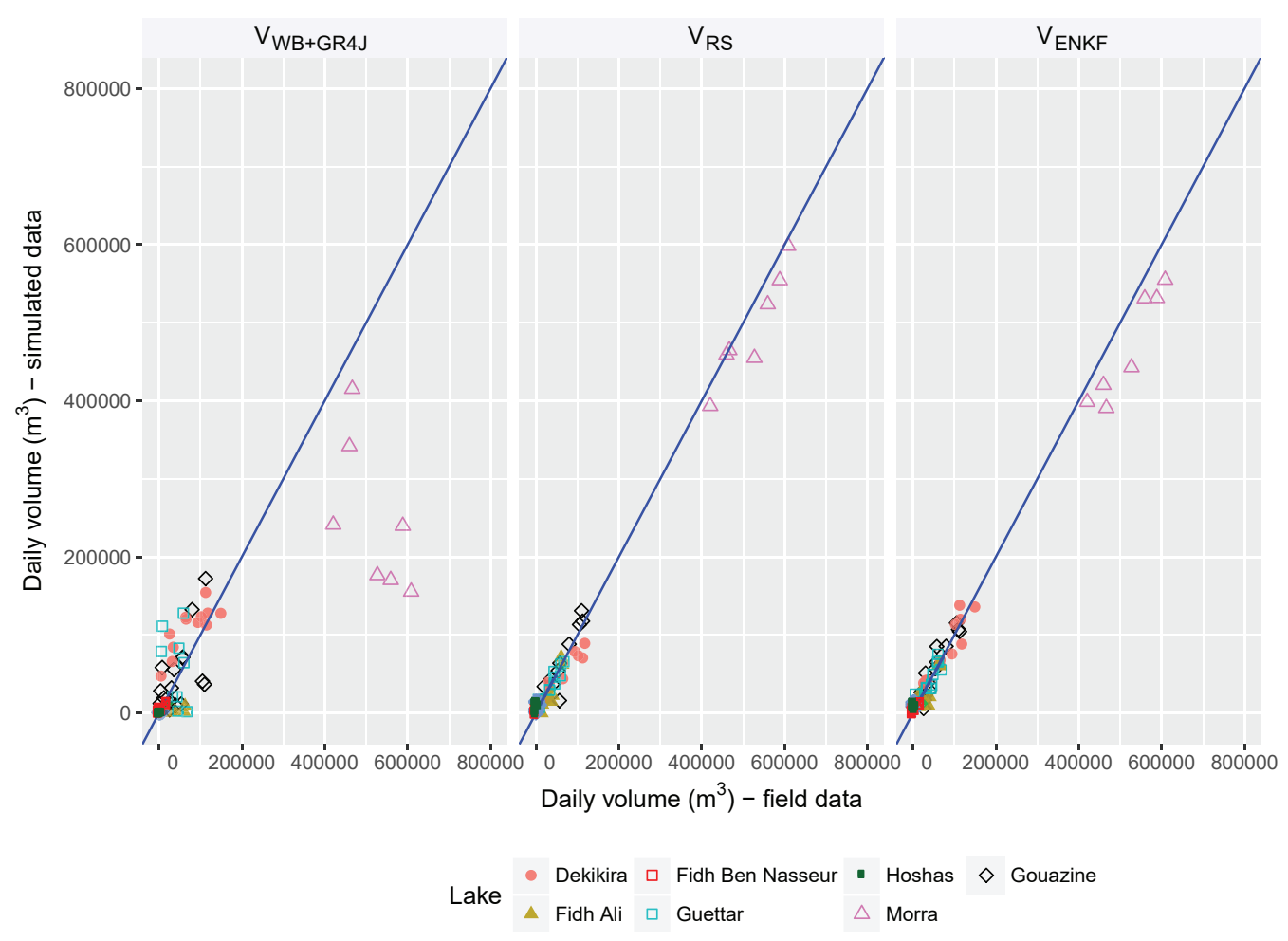

Fig. 11. Scatterplot between modelled and observed mean daily volumes per year for 7 lakes, 1999-2014 
Improvements in the way clouds (especially cirrus clouds) are detected as well as increased temporal and spatial accuracy will help reduce remote sensing errors. Higher spatial resolution will increase precision, while more frequent images will allow outliers to be corrected faster, reducing water availability errors which depend on the lag between subsequent correct observations. Improvements in the method may also be gained by defining specific Kalman gain values for each RS observation to reflect for the presence of clouds at the image level and the associated greater uncertainty over specific observations.

Interestingly, remote sensing uncertainties affected the smaller lakes (e.g. Hoshas) where errors are proportionally more important but also lakes with limited variation in surface area. On Morra for instance, the variations are contained within the \% error of surface area estimates from our MNDWI method. Accordingly, on Morra ENKF outputs for individual observations were heavily affected $(\mathrm{NSE}=0.46)$, but mean annual availability performed well $(\mathrm{NSE}=0.89)$.

\subsection{Ensemble Kalman filter performance as data uncertainties rise}

Figure 12 and table 4 illustrate the difficulties in modelling daily flood dynamics as uncertainties in the data inputs rise. In the absence of upstream rainfall gauges, the performance of the hydrological model degraded (cf. section 3.1.1) and RMSE rose by $28 \%$. The ENKF however continues to improve performance and correct for these errors, with NSE on daily volumes reducing marginally from 0.81 to 0.75 . RMSE values for the daily observations increase by $21 \%$ but remain $46 \%$ lower than the initial WB+GR4J forecast thanks to the remote sensing corrections. Using an average locally derived infiltration rule based on 13 small reservoirs (Ogilvie, 2015) prevented the 
Table 3: Ensemble Kalman Filter performance on mean annual water availability

\begin{tabular}{|c|c|c|c|c|c|c|c|}
\hline \multirow{2}{*}{$\begin{array}{l}\text { Lakes (modelled } \\
\text { period) }\end{array}$} & \multirow{2}{*}{$\begin{array}{l}\text { Mean } \\
\text { daily } \\
\text { volume } \\
\left(\mathrm{m}^{3}\right)\end{array}$} & \multicolumn{3}{|c|}{ NSE } & \multicolumn{3}{|c|}{ RMSE $\left(\mathrm{m}^{3}\right)$} \\
\hline & & $V_{W B+G R 4 J}$ & $V_{R S}$ & $V_{E N K F}$ & $V_{W B+G R 4 J}$ & $V_{R S}$ & $V_{E N K F}$ \\
\hline Gouazine (1999-2014) & 42800 & 0.38 & 0.87 & 0.89 & 36700 & 13500 & 11500 \\
\hline Dekikira (1999-2008) & 59000 & 0.65 & 0.71 & 0.89 & 41600 & 20500 & 14500 \\
\hline Fidh Ali (1999-2005) & 32200 & 0.09 & 0.52 & 0.60 & 35300 & 13500 & 12400 \\
\hline Fidh Ben Nasseur (1999-2001) & 1000 & 0.66 & 0.67 & NA & 4300 & 2400 & 4400 \\
\hline Morra (1999-2014) & 448900 & 0.40 & 0.89 & 0.89 & 304500 & 31700 & 55700 \\
\hline Hoshas (2001-2014) & 800 & 0.37 & 0.11 & 0.09 & 2400 & 8700 & 9500 \\
\hline Guettar (2003-2014) & 29000 & 0.09 & 0.88 & 0.74 & 56500 & 7100 & 10700 \\
\hline
\end{tabular}
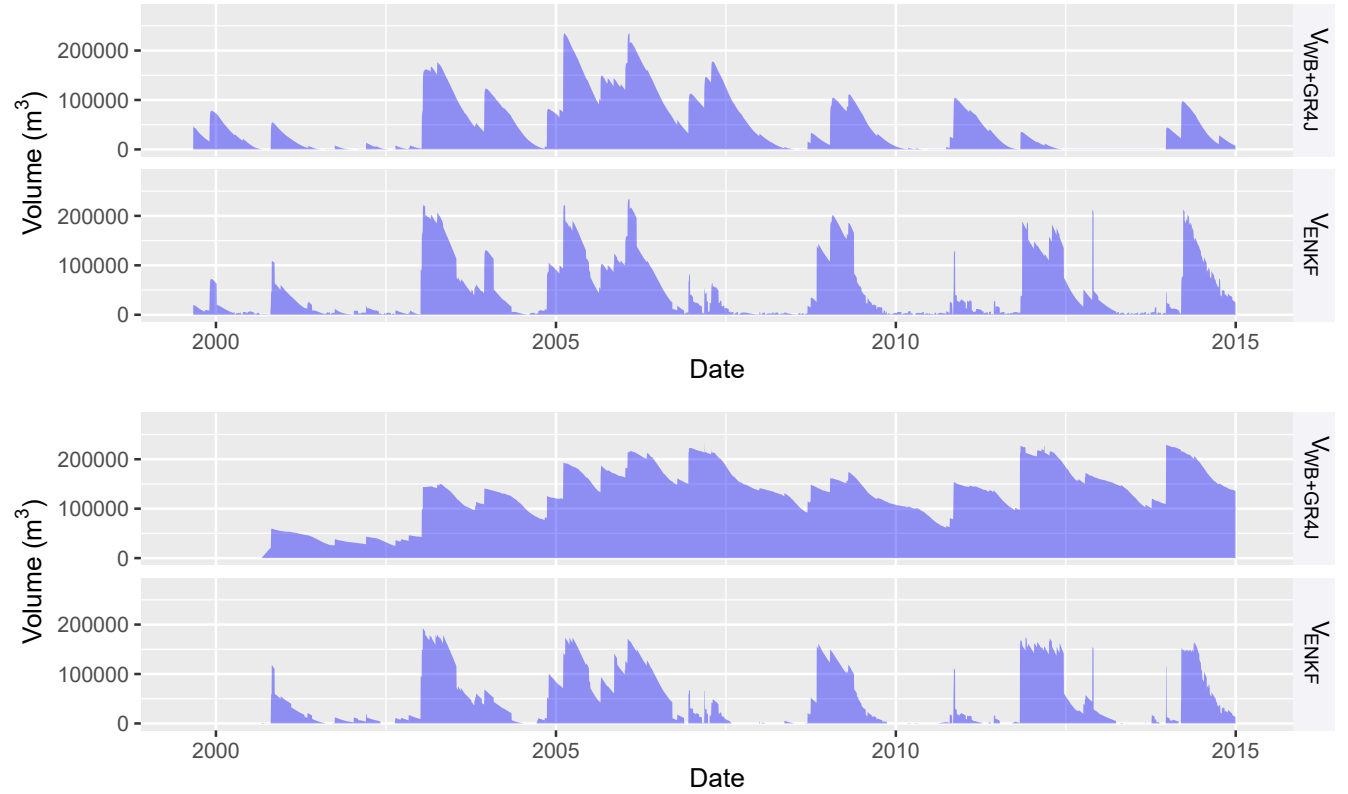

Fig. 12. Modelled daily volumes on Gouazine lake when degrading inputs. Top: with no rainfall gauge in the catchment. Bottom: with the average infiltration value from 15 reservoirs 
model on Gouazine to reproduce the emptying of the lakes between successive events. This lead to a rising drift in volumes and RMSE values of the $V_{W B+G R 4 J}$ initial forecast rising drastically to $97000 \mathrm{~m}^{3}$. Again, the Kalman filter using Landsat observations provided valuable corrections and RMSE values on individual observations remained close $(+15 \%)$ to those with the site specific model. As the confidence in the model inputs \& parameters (on $I, P$,$) degrades or significant additional fluxes can not be modelled reliably$ (releases, withdrawals), the benefit of assimilation with remote sensing observations as expected increases. However the benefit of $V_{E N K F}$ over simply exploiting interpolated $V_{R S}$ values also declines, due to the initial forecast becoming so uncertain. RMSE on $V_{R S}$ remains on average $18 \%$ lower than $V_{E N K F}$ in these four examples (table 4).

When considering ungauged catchments with no locally calibrated GR4J parameters and no site specific HSV relation, the Kalman gain continues to valuably correct the hydrological model's initial forecast, reducing RMSE by $30 \%$ (table 4). The increase in RMSE for $V_{E N K F}$ is however amplified by the uncertainties in $V_{R S}$, due to the surface-volume power relations used. A locally derived power relation was shown to increase errors to near $40 \%$ on Dekikira due to the difficulty in accounting for local lake morphologies and the abrupt changes from silting (Ogilvie et al., 2016a). New techniques based on high spatial resolution sensors open up increased possibilities to acquire at lower costs (time, equipment) sufficient topographic detail to render surface volumes rating curves (Avisse et al., 2017; Baup et al., 2014; van Bemmelen et al., 2016; Massuel et al., 2014a) of multiple reservoirs of different geomorphology. Similarly, data assimilation with Landsat observations could be 
Table 4: Kalman Filter performance on daily volumes when degrading model inputs and parameters

\begin{tabular}{llllllll}
\hline \multirow{2}{*}{ Lake } & Degraded inputs & \multicolumn{3}{c}{ RMSE (m ${ }^{3} /$ day $)$} & \multicolumn{2}{c}{ RMSE increase (\%) } \\
\cline { 3 - 7 } & & $V_{W B+G R 4 J}$ & $V_{R S}$ & $V_{E N K F}$ & $V_{W B+G R 4 J}$ & $V_{R S}$ & $V_{E N K F}$ \\
\hline Gouazine & Rainfall data & 57800 & 25300 & 31400 & $+28 \%$ & $+0 \%$ & $+21 \%$ \\
\hline Gouazine & Infiltration data & 97000 & 25300 & 29800 & $+115 \%$ & $+0 \%$ & $+15 \%$ \\
\hline Dekikira & GR4J parameters and HSV & 52800 & 35800 & 38500 & $+20 \%$ & $+39 \%$ & $+63 \%$ \\
\hline Fidh Ali & GR4J parameters and HSV & 43000 & 20100 & 29000 & $+10 \%$ & $-3 \%$ & $+39 \%$ \\
\hline
\end{tabular}

used to calibrate over time the GR4J parameters, notably $X 1$, based on the estimated runoff. This approach was not explored here due to the rainfall uncertainties observed at this sub basin scale and the temporal resolution of Landsat imagery, which would lead to incorrect quantification of daily runoff and thus calibration of the parameters.

\section{Conclusions}

Landsat surface water estimates coupled with an Ensemble Kalman Filter showed their potential to improve hydrological modelling of small reservoirs. Remote sensing observations provided vital corrections to the flood amplitudes incorrectly estimated by the GR4J model which suffered notably from rainfall detection issues. Conversely, site specific rules on depletion fluxes (infiltration, withdrawals, etc.) led to an accurate modelling of the flood decline, improving over interpolated Landsat observations, limited by reduced temporal resolution. Overall performance reached high skill levels (NSE rose from 0.64 to 0.94 on daily values) and RMSE reduced by two thirds down to $10500 \mathrm{~m}^{3}$ when considering annual water availability. 
Uncertainties from limited data availability (rainfall, infiltration, stage data to calibrate P-Q models) were seen to increase the benefit of the ENKF approach, but can also degrade the hydrological model to a point where it becomes preferable to rely exclusively on interpolated Landsat surface area observations. These performed well except on the smallest lakes, coherent with the medium resolution imagery used here, and due to certain outliers whose interpolation can reduce skill values over short periods. Time series from the new generation of high temporal and spatial resolution satellite imagery (e.g. Sentinel-2) are expected to further improve the accuracy of remote sensing and associated data assimilation approaches on these smaller reservoirs.

The Kalman filter approach may also be varied to seek to correct not individual observations, but rather to estimate model inputs (e.g. rainfall) or model parameters. This could notably be developed to improve hydrological models on ungauged lakes, but would require frequent satellite observations, close to flood peaks to provide sufficient accuracy in estimating daily runoff. Similarly, over decline phases, where sufficient confidence in infiltration and evaporation exists, the remote sensing observations could be used to identify withdrawal rates. The ENKF method may also be enhanced by fine tuning (Moradkhani et al., 2005) the covariances to compose with both sources of uncertainty and provide greater confidence to remote sensing observations over field data based on additional criteria (lake size, cloud presence across image, etc.).

By drastically improving the performance of hydrological modelling in data scarce semi-arid catchments, the Ensemble Kalman filter may improve 
577 local water availability assessments (Wisser et al., 2010) but also provides much needed data on the runoff captured by multiple reservoirs. These may then serve as multiple runoff gauges to be integrated into larger scale models (Gal et al., 2016; Liebe et al., 2009) and feed into the growing discussions over their influence for downstream water users and uses.

\section{Acknowledgements}

We gratefully acknowledge the collaboration from the Direction Générale de l'Aménagement et de la Conservation des Terres Agricoles (DG ACTA) and Direction Générale des Ressources en Eau (DGRE) in Tunis and local representatives at the Kairouan and Siliana Commissariat Régional au Développement Agricole (CRDA). These works were partly financed by the ANR AMETHYST and SICMED DYSHYME projects. Finally, we thank the associate editor and two anonymous reviewers for their comments which helped strengthen the manuscript. 


\section{Appendix A. Supplementary materials}

Table A.1: Infiltration values (mm/day) for small reservoirs in and around the Merguellil upper catchment. Values for Fidh Ali, Fidh Ben Nasseur and Morra were adapted from Lacombe (2007)

\begin{tabular}{ccccc}
\hline Lake & Mean infiltration & Infiltration for $Z_{\min }\left(i_{0}\right)$ & Infiltration for $Z_{\max }$ & Infiltration rise per m $\left(a^{*} 1000\right)$ \\
\hline Dekikira & 2.7 & 2.70 & 2.7 & 0 \\
\hline Hoshas & 28 & 3.62 & 77.1 & 24.50 \\
\hline Guettar & 10 & 10.00 & 10.0 & 0 \\
\hline Gouazine & 9 & 13.00 & 7.5 & -1.38 \\
\hline Fidh Ali & 3.6 & 3.60 & 3.6 & 0 \\
\hline Fidh Ben Nasseur & 7.8 & 3.06 & 12.5 & 3.14 \\
\hline Morra & 2 & 1.48 & 2.5 & 0.53 \\
\hline
\end{tabular}

\section{References}

Alazard, M., Leduc, C., Travi, Y., Boulet, G., Ben Salem, A., 2015. Estimating evaporation in semi-arid areas facing data scarcity: Example of the El Haouareb dam (Merguellil catchment, Central Tunisia). J. Hydrol. Reg. Stud. 3, 265-284. doi:10.1016/j.ejrh.2014.11.007.

Albergel, J., Moussa, R., Chahinian, N., 2003. Les processus hortoniens et leur importance dans la genèse et le développement des crues en zones semi-arides. La Houille Blanche, 65-73.

Albergel, J., Rejeb, N., 1997. Les lacs collinaires en Tunisie : Enjeux, Contraintes et Perspectives. C. R. Acad. Agric. Fr. 83, 77-88.

Aouissi, J., Benabdallah, S., Lili Chabaâne, Z., Cudennec, C., 2018. Valuing scarce observation of rainfall variability with flexible semi-distributed 
hydrological modelling Mountainous Mediterranean context. Sci. Total Envir. 643, 346-356. doi:10.1016/J.SCITOTENV.2018.06.086.

Avalos, J.E., 2004. Modélisation hydrologique globale conceptuelle appliquée aux petits bassins versants en zone semi-aride du nord-Mexique. Rev. Sci. Eau 17, 195-212. doi:10.7202/705530ar.

Avisse, N., Tilmant, A., Müller, M.F., Zhang, H., 2017. Monitoring small reservoirs' storage with satellite remote sensing in inaccessible areas. Hydrol. Earth Syst. Sci. 21, 6445-6459. doi:10.5194/hess-21-6445-2017.

Baccari, N., Boussema, M., Lamachere, J., Nasri, S., 2008. Efficiency of contour benches, filling-in and silting-up of a hillside reservoir in a semi-arid climate in Tunisia. C. R. Geosci. 340, 38-48. doi:10.1016/j.crte.2007.09.020.

Baup, F., Frappart, F., Maubant, J., 2014. Combining high-resolution satellite images and altimetry to estimate the volume of small lakes. Hydrol. Earth Syst. Sci. 18, 2007-2020. doi:10.5194/hess-18-2007-2014.

van Bemmelen, C.W.T., Mann, M., de Ridder, M.P., Rutten, M.M., van de Giesen, N.C., 2016. Determining water reservoir characteristics with global elevation data. Geophys. Res. Lett. 43. doi:10.1002/2016GL069816.

Beven, K., Freer, J., 2001. Equifinality, data assimilation, and uncertainty estimation in mechanistic modelling of complex environmental systems using the GLUE methodology. J. Hydrol. 249, 11-29. doi:10.1016/S00221694(01)00421-8. 
Boulet, G., Kerr, Y., Chehbouni, A., Kalma, J.D., 2002. Deriving catchment-scale water and energy balance parameters using data assimilation based on extended Kalman filtering. Hydrol. Sci. J. 47, 449-467. doi:10.1080/02626660209492946.

Cadier, E., 1996. Hydrologie des petits bassins du Nordeste Brésilien semi-aride: typologie des bassins et transposition écoulements annuels Small watershed hydrology in semi-arid north-eastern Brazil: basin typology and transposition of annual runoff data. J. Hydrol. 182, 117-141. doi:10.1016/0022-1694(95)02933-8.

Clark, M.P., Rupp, D.E., Woods, R.A., Zheng, X., Ibbitt, R.P., Slater, A.G., Schmidt, J., Uddstrom, M.J., 2008. Hydrological data assimilation with the ensemble Kalman filter: Use of streamflow observations to update states in a distributed hydrological model. Adv. Water Resour. 31, 13091324. doi:10.1016/j.advwatres.2008.06.005.

Coron, L., Thirel, G., Delaigue, O., Perrin, C., Andréassian, V., 2017. The suite of lumped GR hydrological models in an R package. Environ. Model. Soft. 94, 166-171. doi:10.1016/J.ENVSOFT.2017.05.002.

Crétaux, J.F., Biancamaria, S., Arsen, A., Bergé-Nguyen, M., Becker, M., 2015. Global surveys of reservoirs and lakes from satellites and regional application to the Syrdarya river basin. Environ. Res. Lett. 10, 015002. doi:10.1088/1748-9326/10/1/015002.

Cudennec, C., Leduc, C., Koutsoyiannis, D., 2007. Dryland hydrology 
in Mediterranean regions - a review. Hydrol. Sci. J. 52, 1077-1087. doi:10.1623/hysj.52.6.1077.

Desconnets, J., Taupin, J., Lebel, T., Leduc, C., 1997. Hydrology of the HAPEX-Sahel Central Super-Site: surface water drainage and aquifer recharge through the pool systems. J. Hydrol. 188-189, 155-178. doi:10.1016/S0022-1694(96)03158-7.

Doumounia, A., Gosset, M., Cazenave, F., Kacou, M., Zougmore, F., 2014. Rainfall monitoring based on microwave links from cellular telecommunication networks: First results from a West African test bed. Geophys. Res. Lett. 41, 6016-6022. doi:10.1002/2014GL060724.

Emery, C.M., Paris, A., Biancamaria, S., Boone, A., Calmant, S., Garambois, P.A., da Silva, J.S., 2017. Large scale hydrological model river storage and discharge correction using satellite altimetry-based discharge product. Hydrol. Earth Syst. Sci. Discuss., 1-54. doi:10.5194/hess-2017-516.

Evensen, G., 2003. The Ensemble Kalman Filter: Theoretical formulation and practical implementation. Ocean Dyn. 53, 343-367. doi:10.1007/s10236-003-0036-9.

Feki, H., Slimani, M., Cudennec, C., 2012. Incorporating elevation in rainfall interpolation in Tunisia using geostatistical methods. Hydrol. Sci. J. 57, 1294-1314. doi:10.1080/02626667.2012.710334.

Feng, M., Sexton, J.O., Channan, S., Townshend, J.R., 2016. A global, high-resolution (30-m) inland water body dataset for 2000: first results 
of a topographic-spectral classification algorithm. Int. J. Digit. Earth 9, 113-133. doi:10.1080/17538947.2015.1026420.

Forkel, M., Carvalhais, N., Verbesselt, J., Mahecha, M., Neigh, C., Reichstein, M., 2013. Trend Change Detection in NDVI Time Series: Effects of Inter-Annual Variability and Methodology. Remote Sens. 5, 2113-2144. doi:10.3390/rs5052113.

Frappart, F., Biancamaria, S., Normandin, C., Blarel, F., Bourrel, L., Aumont, M., Azemar, P., Vu, P.L., Le Toan, T., Lubac, B., Darrozes, J., 2018. Influence of recent climatic events on the surface water storage of the Tonle Sap Lake. Sci. Total Environ. 636, 1520-1533. doi:10.1016/J.SCITOTENV.2018.04.326.

Gal, L., Grippa, M., Hiernaux, P., Peugeot, C., Mougin, E., Kergoat, L., 2016. Changes in lakes water volume and runoff over ungauged Sahelian watersheds. J. Hydrol. 540, 1176-1188. doi:10.1016/j.jhydrol.2016.07.035.

Gao, P., Mu, X.M., Wang, F., Li, R., 2011. Changes in streamflow and sediment discharge and the response to human activities in the middle reaches of the Yellow River. Hydrol. Earth Syst. Sci. 15, 1-10. doi:10.5194/hess15-1-2011.

Gillijns, S., Mendoza, O., Chandrasekar, J., De Moor, B., Bernstein, D., Ridley, A., 2006. What is the ensemble Kalman filter and how well does it work?, in: American Control Conference 2006, IEEE. p. 6. doi:10.1109/ACC.2006.1657419. 
Grunberger, O., Montoroi, J., Nasri, S., 2004. Quantification of water exchange between a hill reservoir and groundwater using hydrological and isotopic modelling (El Gouazine, Tunisia). C. R. Geosci. 336, 1453-1462. doi:10.1016/j.crte.2004.08.006.

He, X., Li, Z., Hao, M., Tang, K., Zheng, F., 2003. Down-scale analysis for water scarcity in response to soil -water conservation on Loess Plateau of China. Agric. Ecosyst. Environ. 94, 355-361. doi:10.1016/S01678809(02)00039-7.

Hengl, T., Heuvelink, G.B., Rossiter, D.G., 2007. About regressionkriging: From equations to case studies. Comput. Geosci. 33, 1301-1315. doi:10.1016/j.cageo.2007.05.001.

Hentati, A., Kawamura, A., Amaguchi, H., Iseri, Y., 2010. Evaluation of sedimentation vulnerability at small hillside reservoirs in the semi-arid region of Tunisia using the Self-Organizing Map. Geomorphology 122, 56-64. doi:10.1016/j.geomorph.2010.05.013.

Hrachowitz, M., Savenije, H., Blöschl, G., McDonnell, J., Sivapalan, M., Pomeroy, J., Arheimer, B., Blume, T., Clark, M., Ehret, U., Fenicia, F., Freer, J., Gelfan, A., Gupta, H., Hughes, D., Hut, R., Montanari, A., Pande, S., Tetzlaff, D., Troch, P., Uhlenbrook, S., Wagener, T., Winsemius, H., Woods, R., Zehe, E., Cudennec, C., 2013. A decade of Predictions in Ungauged Basins (PUB)a review. Hydrol. Sci. J. 58, 1198-1255. doi:10.1080/02626667.2013.803183.

Kingumbi, A., Bargaoui, Z., Ledoux, E., Besbes, M., Hubert, P., 2007. 
Modélisation hydrologique stochastique d'un bassin affecté par des changements d'occupation: cas du Merguellil en Tunisie centrale. Hydrol. Sci. J. 52, 1232-1252. doi:10.1623/hysj.52.6.1232.

Lacombe, G., 2007. Evolution et usages de la ressource en eau dans un bassin versant amenagé semi-aride. Le cas du Merguellil en Tunisie Centrale. Ph.D. thesis. Université Montpellier II.

Lacombe, G., Cappelaere, B., Leduc, C., 2008. Hydrological impact of water and soil conservation works in the Merguellil catchment of central Tunisia. J. Hydrol. 359, 210-224. doi:10.1016/j.jhydrol.2008.07.001.

Leauthaud, C., Belaud, G., Duvail, S., Moussa, R., Grünberger, O., Albergel, J., 2013. Characterizing floods in the poorly gauged wetlands of the Tana River Delta, Kenya, using a water balance model and satellite data. Hydrol. Earth Syst. Sci. 17, 3059-3075. doi:10.5194/hess-17-3059-2013.

Leduc, C., Ben Ammar, S., Favreau, G., Beji, R., Virrion, R., Lacombe, G., Tarhouni, J., Aouadi, C., Zenati Chelli, B., Jebnoun, N., Oi, M., Michelot, J., Zouari, K., 2007. Impacts of hydrological changes in the Mediterranean zone: environmental modifications and rural development in the Merguellil catchment, central Tunisia. Hydrol. Sci. J. 52, 1162-1178. doi:10.1623/hysj.52.6.1162.

Lehner, B., Liermann, C.R., Revenga, C., Vörösmarty, C., Fekete, B., Crouzet, P., Döll, P., Endejan, M., Frenken, K., Magome, J., Nilsson, C., Robertson, J.C., Rödel, R., Sindorf, N., Wisser, D., 2011. High-resolution 
mapping of the world's reservoirs and dams for sustainable river-flow management. Front. Ecol. Environ. 9, 494-502. doi:10.1890/100125.

Li, Q., Gowing, J., 2005. A Daily Water Balance Modelling Approach for Simulating Performance of Tank-Based Irrigation Systems. Water Resour. Manag. 19, 211-231. doi:10.1007/s11269-005-2702-9.

Liebe, J., van de Giesen, N., Andreini, M., 2005. Estimation of small reservoir storage capacities in a semi-arid environment. Phys. Chem. Earth, Parts A/B/C 30, 448-454. doi:10.1016/j.pce.2005.06.011.

Liebe, J.R., van de Giesen, N., Andreini, M., Walter, M.T., Steenhuis, T.S., 2009. Determining watershed response in data poor environments with remotely sensed small reservoirs as runoff gauges. Water Resour. Res. 45, W07410. doi:10.1029/2008WR007369.

Linacre, E., 1994. Estimating U.S. Class A Pan Evaporation from Few Climate Data. Water Int. 19, 5-14. doi:10.1080/02508069408686189.

Ma, H., Yang, D., Tan, S.K., Gao, B., Hu, Q., 2010. Impact of climate variability and human activity on streamflow decrease in the Miyun Reservoir catchment. J. Hydrol. 389, 317-324. doi:10.1016/j.jhydrol.2010.06.010.

Martin-Rosales, W., Leduc, C., 2003. Dynamiques de vidange d'une mare temporaire au Sahel : l'exemple de Banizoumbou (Sud-Ouest du Niger). C. R. Geosci. 335, 461-468. doi:10.1016/S1631-0713(03)00059-2.

Massuel, S., Feurer, D., Ogilvie, A., Calvez, R., Rochette, R., 2014a. Vers l'amélioration du bilan hydrologique des retenues collinaires par la 
prise de vue aéroportée légère, in: Drones et moyens légers aéroportés d'observation, Montpellier, France. p. 1.

Massuel, S., Perrin, J., Mascre, C., Mohamed, W., Boisson, A., Ahmed, S., 2014b. Managed aquifer recharge in South India: What to expect from small percolation tanks in hard rock? J. Hydrol. 512, 157-167. doi:10.1016/j.jhydrol.2014.02.062.

McMahon, T.A., Peel, M.C., Lowe, L., Srikanthan, R., McVicar, T.R., 2013. Estimating actual, potential, reference crop and pan evaporation using standard meteorological data: a pragmatic synthesis. Hydrol. Earth Syst. Sci. 17, 1331-1363. doi:10.5194/hess-17-1331-2013.

Molle, F., 1991. Caractéristiques et potentialités des Açudes du nord-est brésilien. Ph.D. thesis. Université de Montpellier 2, France.

Montoroi, J.P., Grunberger, O., Nasri, S., 2002. Groundwater geochemistry of a small reservoir catchment in Central Tunisia. Appl. Geochem. 17, 1047-1060. doi:10.1016/S0883-2927(02)00076-8.

Moradkhani, H., Sorooshian, S., Gupta, H.V., Houser, P.R., 2005. Dual state - parameter estimation of hydrological models using ensemble Kalman filter. Adv. Water. Resour. 28, 135-147. doi:10.1016/j.advwatres.2004.09.002.

Moussa, R., 2010. When monstrosity can be beautiful while normality can be ugly: assessing the performance of event-based flood models. Hydrol. Sci. J. 55, 1074-1084. doi:10.1080/02626667.2010.505893. 
Mu, Q., Zhao, M., Running, S.W., 2011. Improvements to a MODIS global terrestrial evapotranspiration algorithm. Remote Sens. Environ. 115, 17811800. doi:10.1016/j.rse.2011.02.019.

Mueller, N., Lewis, A., Roberts, D., Ring, S., Melrose, R., Sixsmith, J., Lymburner, L., McIntyre, A., Tan, P., Curnow, S., Ip, A., 2016. Water observations from space: Mapping surface water from 25 years of Landsat imagery across Australia. Remote Sens. Environ. 174, 341-352. doi:10.1016/j.rse.2015.11.003.

Nasri, S., 2007. Caracteristiques et impacts hydrologiques de banquettes en cascade sur un versant semi-aride en Tunisie centrale. Hydrol. Sci. J. 52, 1134-1145. doi:10.1623/hysj.52.6.1134.

Neppel, L., Desbordes, M., Masson, J.M., 1998. Influence de l'évolution dans l'espace et le temps d'un réseau de pluviomètres sur l'observation des surfaces de pluie en fonction de leur aire. Rev. Sci. Eau 11, 43-60. doi:10.7202/705296ar.

Nyssen, J., Clymans, W., Descheemaeker, K., Poesen, J., Vandecasteele, I., Vanmaercke, M., Zenebe, A., Van Camp, M., Haile, M., Haregeweyn, N., Moeyersons, J., Martens, K., Gebreyohannes, T., Deckers, J., Walraevens, K., 2010. Impact of soil and water conservation measures on catchment hydrological response-a case in north Ethiopia. Hydrol. Process. 24, 18801895. doi:10.1002/hyp.7628.

Ogilvie, A., 2015. Upscaling water availability and water use assessments in hydro-sociosystems: the small reservoirs of the Merguellil catchment (Cen- 
tral Tunisia). Ph.D. thesis. Université de Montpellier and King's College London.

Ogilvie, A., Belaud, G., Delenne, C., Bailly, J.S., Bader, J.C., Oleksiak, A., Ferry, L., Martin, D., 2015. Decadal monitoring of the Niger Inner Delta flood dynamics using MODIS optical data. J. Hydrol. 523, 368-383. doi:10.1016/j.jhydrol.2015.01.036.

Ogilvie, A., Belaud, G., Massuel, S., Mulligan, M., Le Goulven, P., Calvez, R., 2016a. Assessing Floods and Droughts in Ungauged Small Reservoirs with Long-Term Landsat Imagery. Geosciences 6, 42. doi:10.3390/GEOSCIENCES6040042.

Ogilvie, A., Le Goulven, P., Leduc, C., Calvez, R., Mulligan, M., 2016b. Réponse hydrologique d'un bassin semi-aride aux événements pluviométriques et aménagements de versant (bassin du Merguellil, Tunisie centrale). Hydrol. Sci. J. 61, 441-453. doi:10.1080/02626667.2014.934249.

Ogilvie, A., Belaud, G., Massuel, S., Mulligan, M., Le Goulven, P., Calvez, R., 2018. Surface water monitoring in small water bodies: potential and limits of multi-sensor Landsat time series. Hydrol. Earth Syst. Sci. Discuss. 1-35. doi:10.5194/hess-2018-19.

Oubanas, H., Gejadze, I., Malaterre, P.O., Mercier, F., 2018. River discharge estimation from synthetic SWOT-type observations using variational data assimilation and the full Saint-Venant hydraulic model. J. Hydrol. doi:10.1016/J.JHYDROL.2018.02.004. 
Overeem, A., Leijnse, H., Uijlenhoet, R., 2013. Country-wide rainfall maps from cellular communication networks. Proc. Natl. Acad. Sci. U.S.A. 110, 2741-5. doi:10.1073/pnas.1217961110.

Pekel, J.F., Cottam, A., Gorelick, N., Belward, A.S., 2016. High-resolution mapping of global surface water and its long-term changes. Nature 540, 418-422. doi:10.1038/nature20584.

Perrin, C., Michel, C., Andréassian, V., 2003. Improvement of a parsimonious model for streamflow simulation. J. Hydrol. 279, 275-289. doi:10.1016/S0022-1694(03)00225-7.

Reichle, R.H., McLaughlin, D.B., Entekhabi, D., 2002. Hydrologic Data Assimilation with the Ensemble Kalman Filter. Mon. Weather Rev. 130, 103-114. doi:10.1175/1520-0493(2002)130<0103:HDAWTE>2.0.CO;2.

Riou, C., 1972. Etude de l'évaporation en Afrique centrale. Cahiers Orstom, Série Hydrologie, 39-52.

Sawunyama, T., Senzanje, A., Mhizha, A., 2006. Estimation of small reservoir storage capacities in Limpopo River Basin using geographical information systems (GIS) and remotely sensed surface areas: Case of Mzingwane catchment. Phys. Chem. Earth, Parts A/B/C 31, 935-943. doi:10.1016/j.pce.2006.08.008.

da Silva, J.S., Calmant, S., Seyler, F., Moreira, D.M., Oliveira, D., Monteiro, A., 2014. Radar Altimetry Aids Managing Gauge Networks. Water Resour. Manag. 28, 587-603. doi:10.1007/s11269-013-0484-z. 
Soti, V., Puech, C., Lo Seen, D., Bertran, A., Vignolles, C., Mondet, B., Dessay, N., Tran, A., 2010. The potential for remote sensing and hydrologic modelling to assess the spatio-temporal dynamics of ponds in the Ferlo Region (Senegal). Hydrol. Earth Syst. Sci. 14, 1449-1464. doi:10.5194/hess14-1449-2010.

Swenson, S., Wahr, J., 2009. Monitoring the water balance of Lake Victoria, East Africa, from space. J. Hydrol. 370, 163-176. doi:10.1016/j.jhydrol.2009.03.008.

Van Der Heijden, S., Haberlandt, U., 2010. Influence of spatial interpolation methods for climate variables on the simulation of discharge and nitrate fate with SWAT. Adv. Geosci. 27, 91-98. doi:10.5194/adgeo-27-91-2010.

Vermeulen, P.T.M., Heemink, A.W., 2006. Model-Reduced Variational Data Assimilation. Mon. Weather Rev. 134, 2888-2899. doi:10.1175/MWR3209.1.

Wackernagel, H., 2004. Géostatistique et assimilation séquentielle de données. H.D.R. Université Pierre et Marie Curie, France.

Wisser, D., Frolking, S., Douglas, E.M., Fekete, B.M., Schumann, A.H., Vörösmarty, C.J., 2010. The significance of local water resources captured in small reservoirs for crop production - A global-scale analysis. J. Hydrol. 384, 264-275. doi:10.1016/j.jhydrol.2009.07.032.

Xie, X., Zhang, D., 2010. Data assimilation for distributed hydrological catchment modeling via ensemble Kalman filter. Adv. Water. Resour. 33, 678-690. doi:10.1016/j.advwatres.2010.03.012. 
$\mathrm{Xu}, \mathrm{H} ., 2$ 2006. Modification of normalised difference water index (NDWI) to enhance open water features in remotely sensed imagery. Int. J. Remote Sens. 27, 3025-3033. doi:10.1080/01431160600589179.

Yamazaki, D., Trigg, M.A., 2016. Hydrology: The dynamics of Earth's surface water. Nature 540, 348-349. doi:10.1038/nature21100.

Zammouri, M., Feki, H., 2005. Managing releases from small upland reservoirs for downstream recharge in semi-arid basins (Northeast of Tunisia). J. Hydrol. 314, 125-138. doi:10.1016/j.jhydrol.2005.03.011.

Zribi, M., Chahbi, A., Shabou, M., Lili-Chabaane, Z., Duchemin, B., Baghdadi, N., Amri, R., Chehbouni, A., 2011. Soil surface moisture estimation over a semi-arid region using ENVISAT ASAR radar data for soil evaporation evaluation. Hydrol. Earth Syst. Sci. 15, 345-358. doi:10.5194/hess15-345-2011. 